\title{
Disinhibition Combines with Excitation to Extend the Operating Range of the OFF Visual Pathway in Daylight
}

\author{
Michael B. Manookin, ${ }^{1}$ Deborah Langrill Beaudoin, ${ }^{2}$ Zachary Raymond Ernst, ${ }^{2}$ Leigh J. Flagel, ${ }^{2}$ and Jonathan B. Demb ${ }^{1,2,3}$ \\ ${ }^{1}$ Neuroscience Program and Departments of ${ }^{2}$ Ophthalmology and Visual Sciences and ${ }^{3}$ Molecular, Cellular, and Developmental Biology, University of \\ Michigan, Ann Arbor, Michigan 48105
}

\begin{abstract}
Cone signals divide into parallel ON and OFF bipolar cell pathways, which respond to objects brighter or darker than the background and release glutamate onto the corresponding type of ganglion cell. It is assumed that ganglion cell excitatory responses are driven by these bipolar cell synapses. Here, we report an additional mechanism: OFF ganglion cells were driven in part by the removal of synaptic inhibition (disinhibition). The disinhibition played a relatively large role in driving responses at low contrasts. The disinhibition persisted in the presence of CNQX and D-AP-5. Furthermore, the CNQX/D-AP-5-resistant response was blocked by L-AP-4, meclofenamic acid, quinine, or strychnine but not by bicuculline. Thus, the disinhibition circuit was driven by the ON pathway and required gap junctions and glycine receptors but not ionotropic glutamate or $\mathrm{GABA}_{\mathrm{A}}$ receptors. These properties implicate the AII amacrine cell, better known for its role in rod vision, as a critical circuit element through the following pathway: cone $\rightarrow$ ON cone bipolar cell $\rightarrow$ AII cell $\rightarrow$ OFF ganglion cell. Rods could also drive this circuit through their gap junctions with cones. Thus, to light decrement, AII cells, driven by electrical synapses with ON cone bipolar cells, would hyperpolarize and reduce glycine release to excite OFF ganglion cells. To light increment, the AII circuit would directly inhibit OFF ganglion cells. These results show a new role for disinhibition in the retina and suggest a new role for the AII amacrine cell in daylight vision.
\end{abstract}

Key words: A2 amacrine cell; circuitry; whole-cell recording; patch clamp; retinal; Y-cell

\section{Introduction}

The retina encodes increments and decrements in light intensity using parallel $\mathrm{ON}$ and OFF pathways (Werblin and Dowling, 1969; Schiller, 1992). ON and OFF ganglion cells dedicate their output range for encoding only half the input range, and thus the split into two pathways apparently doubles the operating range of the visual system (Sterling, 2004). Under cone-driven conditions, the excitatory circuitry for these pathways is well understood. Cones release glutamate onto ON and OFF bipolar cells, which express distinct glutamate receptors at their dendrites [metabotropic glutamate receptor subtype 6 (mGluR6) vs AMPA/kainate] and consequently show opposite responses to both cone glutamate release and light (Slaughter and Miller, 1981; Nakajima et al., 1993; Nomura et al., 1994; DeVries, 2000) (see Fig. $1 B)$. ON and OFF cone bipolar cells release glutamate onto ionotropic receptors to excite the corresponding $\mathrm{ON}$ or OFF ganglion cell type (Diamond and Copenhagen, 1993; Cohen et al., 1994; Chen and Diamond, 2002) (see Fig. $1 B$ ).

In addition to these "vertical glutamate pathways," ganglion cell responses are modulated by synaptic inhibition. For example,

Received Sept. 18, 2007; revised Jan. 30, 2008; accepted March 6, 2008.

This work was supported by National Institutes of Health Grants T32-EY13934, EY14454, and EY07003 (Core Grant). J.B.D. is the recipient of a Research to Prevent Blindness Career Development Award and an Alfred P. Sloan Research Fellowship. We thank Drs. Daniel Green, Gabe Murphy, Fred Rieke, Josh Singer, and Peter Sterling for comments and suggestions on this manuscript.

Correspondence should be addressed to Dr. Jonathan B. Demb, Kellogg Eye Center, University of Michigan, 1000 Wall Street, Ann Arbor, MI 48105. E-mail: jdemb@umich.edu.

DOI:10.1523/JNEUROSCI.4274-07.2008

Copyright $\odot 2008$ Society for Neuroscience $\quad$ 0270-6474/08/284136-15\$15.00/0 under cone-driven conditions, OFF ganglion cells receive inhibitory synaptic input at light onset; the inhibition is driven by an amacrine cell, which is in turn driven by ON bipolar cells (Zaghloul et al., 2003; Roska et al., 2006). Thus, OFF-pathway excitation and ON-pathway inhibition drive the OFF ganglion cell membrane potential in opposite directions to dark and light, respectively. Here, we reveal an additional, unexpected function of this ON-pathway inhibition and probe the underlying amacrine cell circuit.

In experiments below, we show that OFF ganglion cell responses to negative contrast (i.e., light decrement) were driven in part by excitatory synapses, as expected. However, these responses were also driven in part by the removal of inhibition (i.e., disinhibition); the disinhibition played a relatively large role at low contrast. Thus, tonic inhibition at steady mean luminance could be increased or decreased depending on contrast sign. A strong candidate for the source of inhibition is the well studied AII amacrine cell: a bistratified interneuron that interacts with both ON and OFF pathways (Famiglietti and Kolb, 1975). The AII cell is widely studied for its prominent role in rod vision (Bloomfield and Dacheux, 2001; Singer, 2007) (see Fig. 1A). It has been proposed that these cells might be functionally removed from the circuit in bright light (Smith et al., 1986; Mills and Massey, 1995), but AII cells, in fact, respond in bright light (Dacey, 1999; Xin and Bloomfield, 1999; Pang et al., 2007). Furthermore, OFF ganglion cells respond, in bright light, after blocking ionotropic glutamate receptors (iGluRs) (Cohen, 1998; Cohen and Miller, 1999); the only known circuit to explain these 
responses is the following: cone $\rightarrow$ ON cone bipolar cell $\rightarrow$ AII cell $\rightarrow$ OFF ganglion cell (Trexler et al., 2005; Murphy and Rieke, 2006; Pang et al., 2007) (see Fig. 1 B). Below, we provide evidence that this AII circuit explains OFF ganglion cell disinhibition. These results show a new role for disinhibition in the retina and suggest a function for the AII amacrine cell in daylight vision.

\section{Materials and Methods}

Tissue preparation and electrophysiology. Hartley guinea pigs were housed in a $12 \mathrm{~h} \mathrm{light/dark} \mathrm{cycle.} \mathrm{On} \mathrm{the} \mathrm{day} \mathrm{of} \mathrm{an} \mathrm{experiment,} \mathrm{an}$ animal was brought to a room illuminated with red light and anesthetized with ketamine $(100 \mathrm{mg} / \mathrm{kg})$ and xylazine $(10 \mathrm{mg} / \mathrm{kg})$. The animal was then decapitated, and both eyes were removed. All procedures conformed to National Institutes of Health and University of Michigan guidelines for use and care of animals in research. The retina was hemisected under dim white light, and the vitreous, lens, and cornea were removed and discarded. The back of the eye, including the retina, pigment epithelium, choroid, and sclera, was either maintained as a single piece or cut along the vertical midline into two pieces (nasal and temporal halves). Slits were made in each piece of tissue so that the retina would lie flat (Demb et al., 1999), and the tissue was mounted on filter paper with two to three small holes $(0.5$ $\mathrm{mm}$ diameter) punched out. The retina was mounted so that the hole positions were aligned with the dorsal retina. Those areas of retina over the holes could be later visualized using transmitted infrared light. The pieces of retina were stored at room temperature in oxygenated $\left(95 \% \mathrm{O}_{2}\right.$ and $5 \% \mathrm{CO}_{2}$ ) Ames medium (Sigma, St. Louis, $\mathrm{MO}$ ) in a light-tight container until the time of recording (storage time, 30 $\min$ to $5 \mathrm{~h}$ ). At the time of recording, the filter paper, with retina attached, was placed in a chamber on a microscope stage and superfused $(\sim 6 \mathrm{ml} / \mathrm{min})$ with oxygenated $\left(95 \% \mathrm{O}_{2}\right.$ and $\left.5 \% \mathrm{CO}_{2}\right)$ Ames medium heated to $33-35^{\circ} \mathrm{C}$ with an in-line heater (TC-344B; Warner Instruments, Hamden, $\mathrm{CT}$ ).

The retina and electrode were visualized using a cooled CCD camera (Retiga 1300C, Qcapture software; Qimaging, Burnaby, British Columbia, Columbia) mounted on an Olympus (Center Valley, PA) BX51WI microscope. We targeted Y-type/ $\alpha$ ganglion cells by recording from the largest cell bodies in the ganglion cell layer (diameter, $20-25 \mu \mathrm{m})$. Cell type was confirmed by measuring light responses and in some cases by analyzing the dendritic tree, as described below (see Results). A glass electrode (tip resistance, 2-6 M $\Omega$ ) was filled with recording solution $[120 \mathrm{~mm}$ cesium-methanesulfonate, $5 \mathrm{~mm}$ tetraethylammonium (TEA)-Cl, $10 \mathrm{~mm}$ HEPES, $3 \mathrm{~mm} \mathrm{NaCl}, 10 \mathrm{~mm}$ BAPTA, 2 mM QX-314-Cl, 2 mm ATP-Mg ${ }^{2+}, 0.3$ mm GTP-Na ${ }^{+}$, and $0.10 \%$ Lucifer yellow, titrated to $\mathrm{pH} 7.3$ ]. All chemicals were purchased from Sigma (St. Louis, MO) except for BAPTA (Invitrogen, Carlsbad, CA), strychnine (Fisher Scientific, Pittsburgh, PA), and the glutamate-receptor drugs (CNQX, D-AP-5, and L-AP-4; Tocris Bioscience, Bristol, UK).

Membrane current was amplified, continuously sampled at $10 \mathrm{kHz}$, and stored on a computer using a MultiClamp 700A amplifier, Digidata 1322A analog-to-digital board, and pClamp 9 software (Molecular Devices, Sunnyvale, CA). Junction potential $(-9 \mathrm{mV})$ was corrected in all cases. We wrote programs in Matlab (version 7; MathWorks, Natick, MA) to analyze light responses. We corrected for an error in the holding potential introduced by the series resistance. The corrected holding potential $\left(V_{\mathrm{h}}\right)$ was determined by the formula $V_{\mathrm{h}}=V_{\mathrm{h} \text { uncorr }}-\left(I_{\text {leak }} \times R_{\mathrm{S}}\right.$ $\left.\times\left(1-R_{\mathrm{S}_{-} \text {correct }}\right)\right)$, where $V_{\mathrm{h} \_ \text {uncorr }}$ is the apparent (uncorrected) holding potential before the stimulus (in millivolts), $I_{\text {leak }}$ is the leak current (in nanoamperes), $R_{\mathrm{S}}$ is the series resistance (mean $\pm \mathrm{SD}, 18 \pm 6 \mathrm{M} \Omega$; $n=109$ cells), and $R_{\mathrm{S} \text { correct }}$ is the series resistance compensation (typically 0.4$)$. $R_{\mathrm{S}}$ was stable over the recording period (15-57 min). Across cells, $R_{\mathrm{S}}$ increased from $16 \pm 4$ to $21 \pm 8 \mathrm{M} \Omega$ (mean $\pm \mathrm{SD}$ ) between the first and last recording used in the analysis $(n=109)$. We generally excluded cells from the analysis with $R_{\mathrm{S}}>35 \mathrm{M} \Omega$.

Results are from 109 cells: 18 ON cells and 91 OFF cells. The zerocurrent potential, at which no current was required to clamp voltage, was $-43.1 \pm 0.9 \mathrm{mV}$ for ON cells (mean $\pm \mathrm{SEM} ; n=11$ ) or $-65.3 \pm 0.4 \mathrm{mV}$ for OFF cells $(n=38)$. The zero-current potential for a cell was determined from the $x$-intercept of the current-voltage $(I-V)$ plot for the leak current. Below we refer to the zero-current potential as the resting potential $\left(V_{\text {rest }}\right)$, although this potential is determined partly by the composition of the pipette solution. For example, with sharp microelectrodes the resting potential of $\mathrm{ON}$ cells was approximately $-59 \mathrm{mV}$ (Zaghloul et al., 2003), whereas with the present pipette solution the zero-current potential for ON cells was more depolarized by $\sim 16 \mathrm{mV}$; this was probably caused in part by the potassium channel blockers in the pipette solution.

Visual stimuli. The stimulus was displayed on a miniature monochrome computer monitor (Lucivid MR1-103; MicroBrightField, Colchester, VT) projected through the top port of the microscope through a $4 \times$ objective and focused on the photoreceptors (resolution, $640 \times 480$ pixels; $60 \mathrm{~Hz}$ vertical refresh). The relationship between gun voltage and monitor intensity was linearized in software with a lookup table. Stimuli were programmed in Matlab as described previously (Brainard, 1997; Pelli, 1997; Demb et al., 1999). All stimuli were centered on the cell body.

Cells were recorded in the superior retina, in which the cone distribution is $\sim 95 \% \mathrm{M}$-cones and $\sim 5 \% \mathrm{~S}$-cones (Rohlich et al., 1994; Yin et al., 2006). During recording, the cell was exposed to stimuli that fluctuated around a constant mean luminance. Light level is described as the isomerization rate per photopigment molecule (Rhodopsin, $\mathrm{M}$-cone op$\sin$, and $\mathrm{S}$-cone opsin) $\mathrm{S}^{-1}: \mathrm{P}_{\mathrm{R}}{ }^{*}, \mathrm{P}_{\mathrm{M}}{ }^{*}$, and $\mathrm{P}_{\mathrm{S}}{ }^{*}$. Photoisomerization rates were calculated based on the spectral output of the monitor, the intensity of the monitor $\left(\mathrm{W} / \mathrm{mm}^{-2}\right)$ at the plane of the retina, and the photoreceptor properties described by Yin et al. (2006). The typical mean luminance evoked $\sim 10^{4} \mathrm{P}_{\mathrm{R}}{ }^{*}, \sim 5 \times 10^{3} \mathrm{P}_{\mathrm{M}}{ }^{*}$, and $\sim 5 \times 10^{2} \mathrm{P}_{\mathrm{S}}^{*}$. Under these conditions, $\mathrm{M}$-cones and rods contribute approximately equally to the light response, whereas S-cones contribute minimally (Yin et al., 2006). At this light level, rod contributions presumably arise through their gap junctions with cones (Bloomfield and Dacheux, 2001). In some cases, we decreased the light level by 10-, 100-, or 1000-fold. At the two dimmest light levels $\left(\sim 5 \times 10^{1}\right.$ or $\sim 5 \times 10^{0} \mathrm{P}_{\mathrm{M}}^{*} ; \sim 10^{2}$ or $\left.\sim 10^{1} \mathrm{P}_{\mathrm{R}}{ }^{*}\right)$, responses are driven by rods (Yin et al., 2006).

The main protocol consisted of a spot $(0.6 \mathrm{~mm}$ diameter $)$ presented for $200 \mathrm{~ms}$ alternating with $800 \mathrm{~ms}$ at mean luminance (i.e., $1 \mathrm{~Hz}$ presentation rate). Spot contrast was an increment (for ON cells) or decrement (for OFF cells) of $2.5,5,10$, or $80 \%$ of the mean luminance. In most conditions, responses were averaged over 12 repeats at 2.5 and $5 \%$ contrast and over six repeats at 10 and $80 \%$ contrast. In the presence of CNQX, D-AP-5, and either strychnine or bicuculline, there were typically oscillations in the response, uncorrelated with the light stimulus, that were not blocked by further adding the nicotinic acetylcholine receptor antagonist D-tubocurarine (100 $\mu \mathrm{M} ; n=2$ cells); thus, the oscillations apparently arose from residual glutamate responses or from inhibition. Under these conditions, $10 \%$ contrast spot responses were averaged over 300 repeats. These were compared with responses averaged over 100 repeats in the other conditions.

Analysis. We measured the inward current to a flash by averaging over $80 \mathrm{~ms}$ centered on the maximal response. Data are reported as mean \pm SEM. Statistical significance was determined using a paired $t$ test unless otherwise indicated.

Current responses to contrast flashes (see Fig. $4 B$ ) were fit with the following equation (least-squares fit):

$$
R(c)=R_{\max } \frac{c^{n}}{c_{50}^{n}+c^{n}},
$$

where $R(c)$ is the response at a given contrast level, $c$ is stimulus contrast, $R_{\max }$ is an asymptotic scale factor, $n$ is the steepest slope of the contrastresponse function, and $c_{50}$ is the contrast gain (contrast that evokes the half-maximal current response) (Albrecht and Hamilton, 1982).

For the conductance analysis, we analyzed the $I-V$ plot for responses evoked at multiple holding potentials. The current responses at each contrast were fit with a line, and these data were then used to determine the excitatory and inhibitory conductances ( $g_{\text {excitation }}$ and $g_{\text {inhibition }}$, respectively) according to the following equations (Borg-Graham, 2001; Taylor and Vaney, 2002): 


$$
\begin{aligned}
& g_{\text {excitation }}=\frac{g_{\text {total }}\left(E_{\text {total }}-E_{\text {inhibition }}\right)}{E_{\text {excitation }}-E_{\text {inhibition }}}, \\
& g_{\text {inhibition }}=\frac{g_{\text {total }}\left(E_{\text {total }}-E_{\text {excitation }}\right)}{E_{\text {inhibition }}-E_{\text {excitation }}},
\end{aligned}
$$

where $E_{\text {total }}$ is the reversal potential of the lightevoked response ( $x$-intercept of the linear fit), $g_{\text {total }}$ is the total conductance (slope of the linear fit), and $E_{\text {excitation }}$ and $E_{\text {inhibition }}$ are the excitatory and inhibitory reversal potentials, respectively.

The reversal potential for inhibitory synapses ( $E_{\text {inhibition, }}$; i.e., $\mathrm{Cl}^{-}$reversal) was calculated as $-67 \mathrm{mV}$. To test this calculation, we blocked synaptic transmission with $\mathrm{CoCl}_{2}(3$ or $6 \mu \mathrm{M})$ and measured the reversal potential of the conductance evoked by adding the $\mathrm{GABA}_{\mathrm{A}}$ agonist muscimol (10 or $100 \mu \mathrm{M}$; Tocris Bioscience) to the bath. Before and after adding muscimol, we measured currents after stepping to several holding potentials around $V_{\text {rest }}$; the muscimolevoked conductance was measured by subtracting the two sets of current measurements. In some cases, TEA-Cl $(10 \mathrm{~mm})$ was added to the bath solution to block $\mathrm{K}^{+}$channels. Adding $\mathrm{CoCl}_{2}$ and TEA-Cl to the Ames medium increased osmolarity by up to $\sim 10 \%$ and shifted $E_{\mathrm{Cl}}$ slightly negative to that calculated for Ames medium alone. However, the reversal potential of the muscimol-evoked conductance was $-2 \pm$ $2 \mathrm{mV}$ from the calculated $E_{\mathrm{Cl}}(n=5 \mathrm{OFF}$ cells, $1 \mathrm{ON}$ cell $)$, suggesting that the calculated $E_{\mathrm{Cl}}$ is appropriate for the conductance analysis used in this study.

The conductance analysis also assumed that the $I-V$ plots could be well fit by a straight line. At high contrast, however, many OFF cells showed a J-shaped $I-V$ curve, suggesting the contribution of an NMDA conductance. For these responses, we analyzed conductance in the subset of cells in which there were at least three current measurements with $V_{\text {hold }}$ positive to $-40 \mathrm{mV}$, in which the nonlinearity associated with NMDA conductances would have minimal effect.

Interpretation of $\mathrm{I}-\mathrm{V}$ plots for light-evoked responses. To measure synaptic conductance, ganglion cell responses were measured at a series of holding potentials ( $V_{\text {hold }}$ values). Leak-subtracted response amplitude was plotted versus $V_{\text {hold }}$ in an $I-V$ plot, in which the slope indicates the total conductance evoked by the spot and the $x$-intercept indicates the associated reversal potential. In this case, the conductance and reversal potential for the spot response are likely to reflect not a single neurotransmitter conductance but rather the sum of two or more conductances in parallel. For example, if the response were mediated by a glutamate synapse in parallel with a "feedforward" inhibitory synapse (GABA or glycine), there would be an increase in two conductances (and a positive slope on the $I-V$ plot) with a reversal potential between the reversals for the excitatory cation channels $(0 \mathrm{mV})$ and the inhibitory receptor channels $(-67 \mathrm{mV}$; see above). Thus, a reversal between 0 and $-67 \mathrm{mV}$ is consistent with an increase in two conductances. If the response is instead mediated by a glutamate synapse in parallel with the withdrawal of an inhibitory synapse, there would be an increase in an excitatory conductance plus a decrease in an inhibitory conductance (disinhibition). The sum of these two influences would generate one of three possible patterns. First, if the magnitude of the excitation is greater than the magnitude of the disinhibition, the summed conductance would be positive and the reversal potential would be $>0 \mathrm{mV}$. Second, if the magnitudes of the excitation and disinhibition are equal, the summed conductance would have a slope of zero with no reversal. Third, if the magnitude of the excitation is less than the magnitude of the disinhibition, the summed conductance would be negative with a reversal less than $-67 \mathrm{mV}$.

Cell labeling and tissue fixation. In a subset of cells from this study $(n=$ 9 ), we analyzed dendritic morphology and stratification. These cells were combined with others recorded in related studies from our laboratory $(n=33)$. During whole-cell recording, Lucifer yellow in the pipette solution filled the dendritic tree of the cell. After recording, the tissue was fixed for $1 \mathrm{~h}$ in $4 \%$ paraformaldehyde (Electron Microscopy Sciences, Hatfield, PA) in $0.1 \mathrm{~m}$ PBS (Sigma) at room temperature and then stored in $0.1 \mathrm{M}$ PBS at $2-8^{\circ} \mathrm{C}$.

Immunocytochemistry. A purpose of filling ganglion cells was to determine their dendritic stratification in the inner plexiform layer (IPL) (Fig. 1). The tissue was thus reacted with an antibody against Lucifer yellow to amplify the fluorescence in the dendritic tree. The retina was further stained with a nuclear dye to label cell bodies in the ganglion cell layer (GCL) and inner nuclear layer (INL); these cell layers define the boundaries of the IPL. Two IPL strata, corresponding to the dendrites of ON and OFF cholinergic (starburst) amacrine cells, were also labeled with an antibody against choline acetyltransferase (ChAT) to mark standard positions in the IPL (Yamada et al., 2005; Zhang et al., 2005).

The fixed tissue was incubated for $1 \mathrm{~h}$ in $6 \%$ normal donkey serum (NDS) (Jackson ImmunoResearch, West Grove, PA) and 1\% Triton $\mathrm{X}-100$ (Sigma) in $0.05 \mathrm{~m}$ Tris-buffered saline (TBS) (Sigma) to permeabilize the tissue and block nonspecific immunolabeling. The tissue was rinsed for $5 \mathrm{~min}$ in $0.05 \mathrm{M} \mathrm{TBS}$ and then incubated overnight at $4^{\circ} \mathrm{C}$ in blocking buffer ( $2 \%$ NDS, $0.2 \%$ Triton X-100 in $0.05 \mathrm{~m}$ TBS) plus goat anti-ChAT antibody (1:200 dilution; Millipore Bioscience Research Reagents, Temecula, CA) and rabbit anti-Lucifer yellow antibody (1:2000 dilution; Invitrogen). Next, the tissue was rinsed for $30 \mathrm{~min}$ in $0.05 \mathrm{~m} \mathrm{TBS}$ and then incubated for $45 \mathrm{~min}$ in secondary antibody: donkey anti-goat bound to cyanine 3 (Cy3) (1:200 dilution; Jackson ImmunoResearch) and donkey anti-rabbit bound to FITC (1:400 dilution; Jackson ImmunoResearch) in blocking buffer. The tissue was rinsed for $30 \mathrm{~min}$ in 0.05 $\mathrm{M}$ TBS and incubated for $30 \mathrm{~min}$ in $0.2 \%$ ToPro- 3 iodide (Invitrogen) in $0.1 \mathrm{M}$ PBS. The tissue was rinsed for $30 \mathrm{~min}(0.1 \mathrm{M}$ PBS) and subsequently mounted with Vectashield (Vector Laboratories, Burlingame, CA) and coverslipped. Glass spacers, made from coverslips (0.13-0.17 mm thick; Fisherbrand; Fisher Scientific, Hampton, NH), were inserted between the coverslip and slide, on opposite sides of the tissue, to prevent tissue compression.

Confocal microscopy. The retina was imaged with an Olympus FluoView 300 confocal microscope, and images were captured with FluoView 


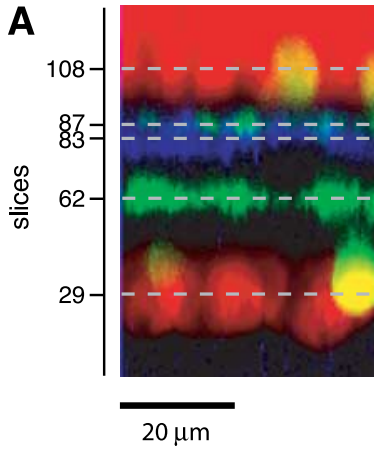

$20 \mu \mathrm{m}$
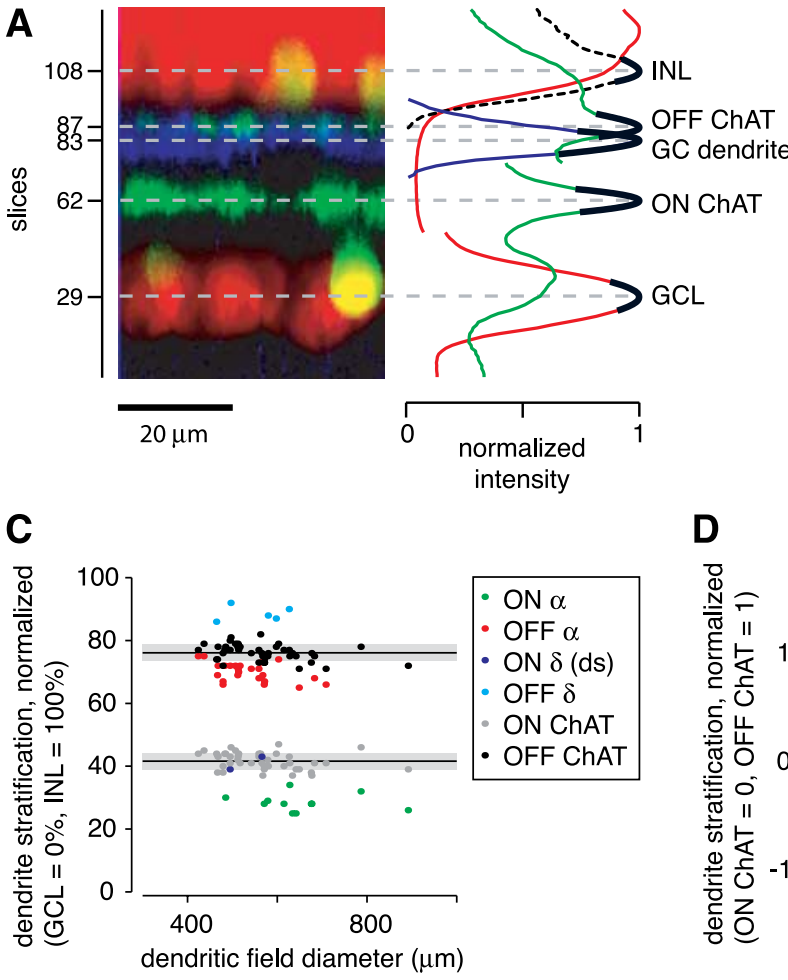

B

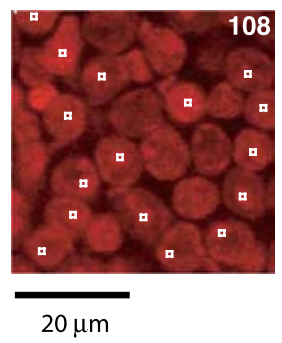

D

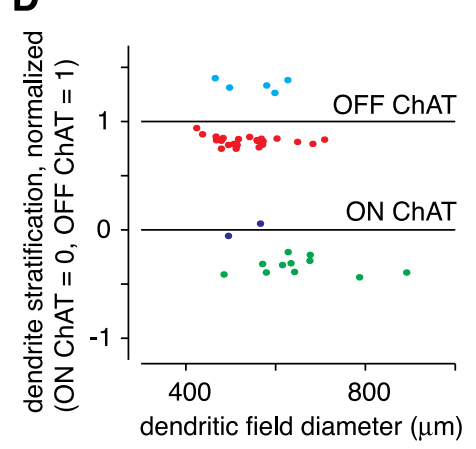

Figure 2. Morphological properties of ganglion cells with large somas in guinea pig retina. $A$, Vertical projection of a stack of confocal images, showing the level of ganglion cell (GC) dendrites, nuclear layer boundaries (INL and GCL), and starburst amacrine cell dendrites (ON and OFF ChAT bands). The plot at right shows the normalized intensity for the GC dendrite (blue), the nuclear dye (red), and the ChAT labeling (green). The ganglion cell layer and inner nuclear layer peaks were normalized separately, resulting in two discontinuous red lines. The two ChAT band peaks were normalized separately, resulting in two discontinuous green lines. The dashed black line plots ToPro-3 intensity within the boxed regions shown in $\boldsymbol{B}$. Solid black lines are polynomial fits used to define the fluorescent intensity peaks. Plotted at these peak positions are the horizontal dashed gray lines, which indicate the position of the ganglion cell layer (slice 29), the ON (inner) ChAT band (slice 62), the OFF (outer) ChAT band (slice 87), and an 0FF $\alpha$ cell dendrite (slice 83). B, Confocal image of slice 108 showing ToPro-3-labeled nuclei. The small boxes overlie selected central regions of nuclei in the inner most layer of the INL. C, The dendritic stratification depths within the IPL of ON $\alpha$ cells, OFF $\alpha$ cells, OFF $\delta$ cells, ON $\delta$ (direction-selective) cells, and the corresponding position of (hAT bands in the same tissues (black or gray dots). Ganglion cell dendrite and ChAT band depths are plotted as a function of ganglion cell dendritic field diameter. Solid lines show the mean of each ChAT band; gray boxes show \pm 1 SD of these bands. D, Normalized dendrite position of cells in C. The stratification in C was normalized relative to the ChAT bands measured in the same tissue (ON ChAT band, 0 ; OFF (hAT band, 1).

software (Olympus). The dendritic field of a filled ganglion cell was captured with a through focal series ( $z$-stack) at $2 \mu \mathrm{m}$ intervals with a $40 \times$ oil objective [numerical aperture (NA) 1.3] and projected onto a single plane. The dendritic field was larger than the field of view, and so multiple projection images were assembled in Photoshop (Adobe Systems, San Jose, CA). In addition, one or two $z$-stacks were taken using a $60 \times$ oil objective (NA 1.4) at $0.5 \mu \mathrm{m}$ intervals starting at the inner (vitreal) side of the GCL and ending within the middle of the INL. These $z$-stacks were used to determine dendrite position within the IPL.

Morphological analysis. A ganglion cell dendritic field diameter was measured by outlining the dendritic tree using Adobe Photoshop and software written in Matlab. We report dendritic tree diameter as the diameter of a circle with area equivalent to the polygon.

Confocal $z$-stacks were analyzed with programs written in Matlab. FluoView software generated a $z$-stack for each fluorescent signal, the dimensions of which were $512 \times 512$ pixels $(236 \times 236 \mu \mathrm{m})$ in the $x-y$ image plane and typically comprised $120-160$ slices $(60-80 \mu \mathrm{m})$ in the $z$ dimension. The $z$-stacks were loaded into Matlab, and a projection of each fluorescent signal was displayed by averaging the stacks across the $z$-dimension for FITC (ganglion cell morphology) and Cy3 signals (ChAT labeling). We used custom Matlab programs to measure these signals, but other commercial software could be used instead (Yamada et al., 2005). For display purposes, the "levels" were adjusted in Adobe
Photoshop to reduce noise; quantitative analysis, however, is based on raw data.

When inspecting the $z$-stacks, it was evident that the tissue was often warped. However, by analyzing a smaller area in the $x-y$ dimension $(100 \times 100$ pixels; $46 \times 46 \mu \mathrm{m})$, the effect of this distortion was minimized (Fig. $2 A$ ). The user selected three to nine such small areas for analysis, and measurements were averaged over the analyses from these individual areas. Areas were selected over distal regions of the ganglion cell dendritic tree at which point the dendrites were well stratified. Within each region, the slices of interest were identified as follows. To identify slices centered on ChAT bands and ganglion cell dendrites, the fluorescent signals were plotted as a function of slice number (Fig. 2A), and the user selected the approximate peaks of the $\mathrm{Cy} 3$ fluorescence (ChAT bands) and the FITC fluorescence (ganglion cell dendrite). To identify slices at the IPL borders, the user viewed a $z$-stack of the Cy5 fluorescences (ToPro-3labeled nuclei) and selected the slice near the middle of the GCL and the slice at the IPL/INL border.

Additional analysis localized the IPL/INL boundary more precisely. The user selected the $x-y$ position of the central point of multiple cell bodies within the slice containing the initial cells on the vitreal (inner) side of the INL (Fig. $2 B$ ). These central points included the nucleolus of a cell, which was typically the brightest region in the image. At each of these points, a $3 \times 3$ pixel $(1.4 \times 1.4 \mu \mathrm{m})$ region of interest ("boxed regions") was used to compute fluorescent ToPro-3 signal as a function of slice number. These boxed regions encompassed an intense area of fluorescence in the most proximal (vitreal) layer of cells (by design) but only occasionally contained such a signal (by chance) in more distal cell bodies. Thus, by summing the fluorescence across boxed regions, a sharp peak in fluorescence was generated at the first layer of cell bodies in the INL, i.e., those at the IPL/INL border (Fig. $2 A$, dashed black line).

The peak of each fluorescent signal was used to determine the percentage depths of dendrites within the IPL. Third-order polynomials were fitted (using standard fitting routines in Matlab) around the estimated fluorescent peaks associated with the GCL, ChAT bands, ganglion cell dendrites, and INL (Fig. $2 A$ ). Fits were made to six to eight points $(3-4 \mu \mathrm{m})$ around the peak. The peak of the fitted line was used to define a given cellular or dendritic layer. The IPL width was calculated as the distance between the GCL and the INL peaks. Given the IPL width and GCL and INL positions, the positions of the ChAT bands and ganglion cell dendrites were expressed as a percentage depth through the IPL from $0 \%$ at the GCL/IPL border to $100 \%$ at the IPL/INL border. The IPL thickness was $38 \pm 4 \mu \mathrm{m}$ (mean \pm $\mathrm{SD} ; n=42$ ). Measured positions of ChAT bands showed variability (SD) across tissues of $\sim 3 \%$ (see Results), which corresponds to $\sim 1.2 \mu \mathrm{m}$.

\section{Results}

Targeting and identification of Y-type/ $\alpha$ ganglion cells

We recorded from ganglion cells in an in vitro preparation of the guinea pig retina (Demb et al., 1999, 2001b) (see Materials and Methods). We targeted ON and OFF Y-type/ $\alpha$ ganglion cells by recording from the largest cell bodies (20-25 $\mu \mathrm{m}$ diameter) in the GCL. In several cases, we filled the cells to reveal the morphology and confirm the cell type. We report on the morphological 
features of cells both from the present study ( $n=9$ cells) and those from a wider series of studies from our laboratory $(n=42$ cells in total). The cells that had the characteristic physiological features of Y-type/ $\alpha$ cells as defined by previous studies (i.e., brisk-transient responses; center-surround receptive fields; nonlinear spatial summation) (Enroth-Cugell and Robson, 1966; Hochstein and Shapley, 1976; Demb et al., 2001b) had wide dendritic trees and a characteristic position of their dendrites in the IPL. The OFF Y-type/ $\alpha$ cells $(n=24)$ had dendritic tree diameters of $535 \pm 72 \mu \mathrm{m}$ (mean \pm SEM) and stratified at $70 \pm 3 \%$ depth in the IPL; this position is on the vitreal side of the nearby OFF ChAT band $(76 \pm 3 \% ; n=42)$ (see Materials and Methods) (Fig. 2C). The ON Y-type/ $\alpha$ cells $(n=11)$ had dendritic tree diameters of $652 \pm 109 \mu \mathrm{m}$ and stratified at $28 \pm 3 \%$; this position is on the vitreal side of the nearby ON ChAT band (42 $\pm 3 \%$; $n=42$ ) (Fig. 2C). Thus, ON or OFF Y-type/ $\alpha$ cells in the guinea pig stratified on the vitreal side of the nearby ON or OFF ChAT band, similar to the dendrite positions of $\alpha$ cells in the rabbit retina (Zhang et al., 2005).

When targeting large cell bodies, two other cell types were occasionally recorded but could be distinguished from the Ytype/ $\alpha$ cells. One type was an OFF cell $(n=5)$, with a wide dendritic tree diameter $(552 \pm 69 \mu \mathrm{m})$ that stratified between the OFF ChAT band and the INL at $89 \pm 2 \%$ (Fig. 2C). A second type was the ON direction-selective (DS) cell $(n=2)$ (Amthor et al., 1989), which had a diameter of $\sim 530 \mu \mathrm{m}$ and costratified with the ON ChAT band (Fig. 2C). For all cells, we also plotted the anatomical data in a second normalized coordinate system, in which dendrite positions are shown relative to the two ChAT band positions measured in the same tissues (Fig. 2D). Here, it is evident that there are four clusters distinguished by their dendritic stratification level relative to the ChAT bands. These four cell types in guinea pig resemble those four cell types with large cell bodies in the rat retina: ON and OFF Y-type/ $\alpha$ and ON and OFF $\delta$ ganglion cells (in which the $\mathrm{ON} \delta$ cell is presumably the ON DS cell) (Peichl, 1989). The OFF $\delta$ cell was also reported in the mouse retina and had similar properties to the guinea pig OFF $\delta$ cell: a large soma and dendritic tree diameter, with dendrite stratification near the INL (Tagawa et al., 1999; Margolis and Detwiler, 2007).

Other features of the Y-type/ $\alpha$ cells were consistent with previous measurements with sharp electrodes (Zaghloul et al., 2003) and allowed us to distinguish OFF $\alpha$ and $\delta$ cells based on the physiology alone. We measured $I-V$ plots to full-contrast step responses of a spot $(0.6 \mathrm{~mm}$ diameter $)$. At a holding potential near $-50 \mathrm{mV}$, the ON Y-type/ $\alpha$ cell showed a transient inward current at light onset and an outward current at light offset (Fig. $3)$. The responses to light onset and offset both reversed between $E_{\text {cation }}(0 \mathrm{mV})$ and $E_{\mathrm{Cl}}(-67 \mathrm{mV})$ (see Materials and Methods). Thus, the ON cell response arose from the modulation of a pair of excitatory and inhibitory conductances that were increased or decreased in parallel (Zaghloul et al., 2003). The OFF Y-type/ $\alpha$ cell showed a different pattern: a transient inward current $\left(V_{\text {hold }}\right.$ of approximately $-50 \mathrm{mV}$ ) at light offset that reversed near $0 \mathrm{mV}$ with a transient outward current at light onset that reversed near $-80 \mathrm{mV}$ (Fig. 3). Thus, the OFF cell response arose primarily from excitation at light offset and inhibition at light onset (Zaghloul et al., 2003). These conductances are analyzed in more detail at multiple contrast levels in the remainder of the paper.

In the $I-V$ plot for the light offset response, some OFF Y-type/ $\alpha$ cells showed a relatively linear relationship (Fig. 3, OFF $\alpha_{1}$ ), whereas others showed a more nonlinear relationship (Fig. 3, OFF $\alpha_{2}$ ): a $J$-shaped pattern that indicated a contribution from NMDA recep- tors (Cohen, 1998; Chen and Diamond, 2002; Sagdullaev et al., 2006). However, cells with or without the J-shaped $I-V$ plot showed a similar time course of their step response (Fig. 3), and their dendrites stratified in similar positions in the IPL (Fig. 2C,D). Thus, we consider these two patterns in the $I-V$ plot to represent diversity within the OFF Y-type/ $\alpha$ cell population. At present, it is unclear why the apparent NMDA contribution varied across cells.

The OFF $\delta$ cell showed a distinct pattern from the OFF Ytype/ $\alpha$ cells: a more sustained response to light offset with a negative slope conductance in the $I-V$ plot (Fig. 3), and thus the OFF $\delta$ cell could be distinguished from the OFF Y-type/ $\alpha$ cell based on its physiology alone. The focus in the remainder of the study is on the ON and OFF Y-type/ $\alpha$ cells, which we refer to simply as ON and OFF cells.

\section{Ganglion cell membrane current responses at low and high contrast}

The above step response measurements were acquired using a contrast-reversing spot stimulus that changed its contrast polarity above and below the mean luminance. In most of the following experiments, we instead measured responses to a $200 \mathrm{~ms}$ spot stimulus, in which spot contrast was $2.5,5,10$, or $80 \%$ and defined as an increment or decrement in intensity relative to a steady mean luminance. The contrast was matched to the sign of the center: decrement stimuli for OFF cells and increment stimuli for ON cells.

Contrast responses were measured while holding voltage near the resting potential. In all cells, the spot evoked an excitatory inward current followed by a "rebound" outward current (Fig. $4 A$ ). Below we focus on the excitatory inward current. The size of the inward current increased with contrast (Fig. 4). OFF cells showed a wider response range than $\mathrm{ON}$ cells, as indicated by a larger response amplitude at $80 \%$ contrast (OFF cells, $790 \pm 74$ $\mathrm{pA}, n=38$ cells; ON cells, $219 \pm 50 \mathrm{pA}, n=11$ cells; $p<0.01$, unpaired $t$ test) (Fig. $4 B$ ). Notably, there were measurable responses, in both OFF and ON cells, at low contrast levels (2.5$10 \%)$. Below, we analyze responses at several contrast levels to reveal the underlying synaptic conductances and to understand how these conductances change with contrast level.

\section{Disinhibition contributes to OFF cell responses}

In ON cells $(n=11)$, both low- and high-contrast responses showed an increased conductance $(2.5 \%, 1.1 \pm 0.2 \mathrm{nS} ; 5 \%, 2.1 \pm$ $0.3 \mathrm{nS} ; 10 \%, 4.4 \pm 0.7 \mathrm{nS} ; 80 \%, 12.2 \pm 1.9 \mathrm{nS}$ ) with a reversal potential that implied a mix of excitation and feedforward inhibition (Fig. 5B) (see Materials and Methods). Furthermore, the reversal potential was similar at low contrast $(2.5 \%,-35 \pm 5 \mathrm{mV}$; $5 \%,-38 \pm 3 \mathrm{mV} ; 10 \%,-36 \pm 2 \mathrm{mV})$ and high contrast $(80 \%$, $-39 \pm 2 \mathrm{mV})$, suggesting that the relative weight of excitation and inhibition was fixed and independent of contrast level.

OFF cells showed a different pattern of results. At low contrast, OFF cell responses showed a negative slope on the $I-V$ plot (Fig. $5 B$ ), and thus these responses were driven primarily by a decreased conductance $(2.5 \%,-0.32 \pm 0.05 \mathrm{nS} ; 5 \%,-0.66 \pm$ $0.14 \mathrm{nS} ; 10 \%,-0.4 \pm 0.4 \mathrm{nS} ; n=38$ cells $)$. In raw traces, this result was reflected by an increased inward current at positive holding potentials, which is opposite to the pattern of the response in ON cells (Fig. $5 A$, arrows). At high contrast ( $80 \% ; n=$ $21)$, there was an increased conductance $(15.3 \pm 2.7 \mathrm{nS})$ with a reversal potential that was, on average, positive to $0 \mathrm{mV}(+16 \pm$ $9 \mathrm{mV}$ ). The positive value of the reversal potential indicates a response driven primarily by glutamate release from bipolar cells in parallel with a net decrease in inhibition relative to a baseline 
A

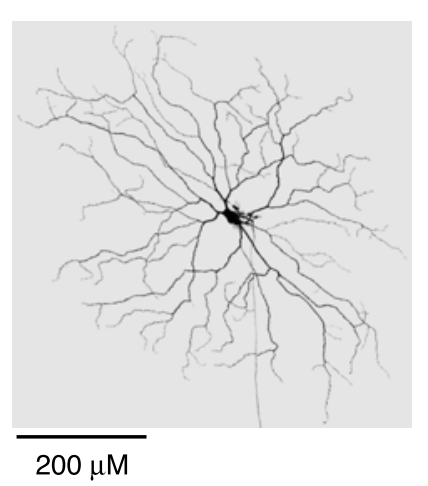

B
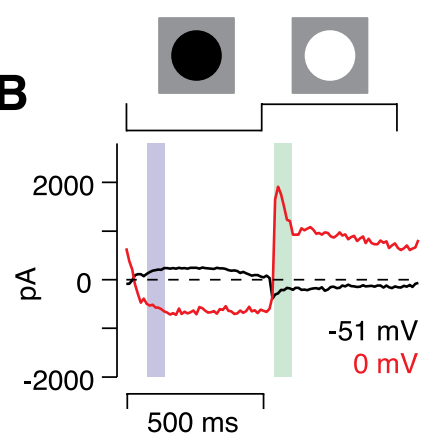

C

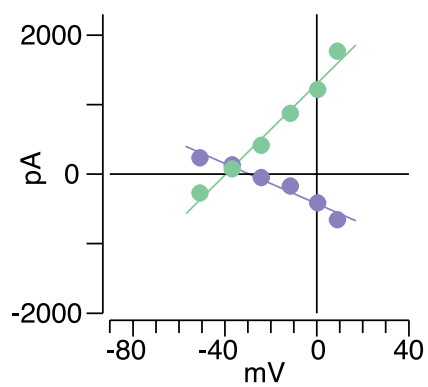

OFF $\alpha_{1}$
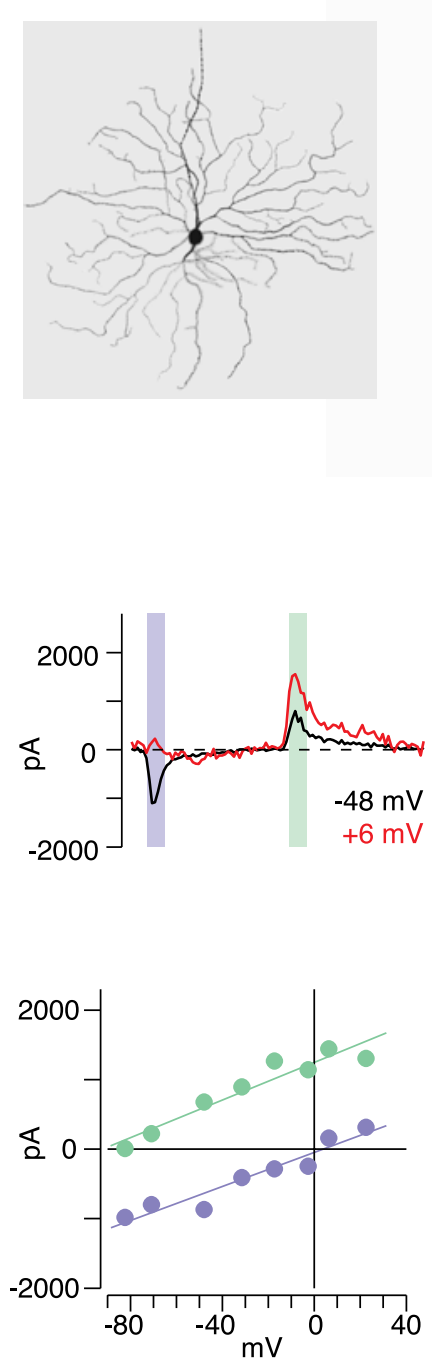

OFF $\alpha_{2}$
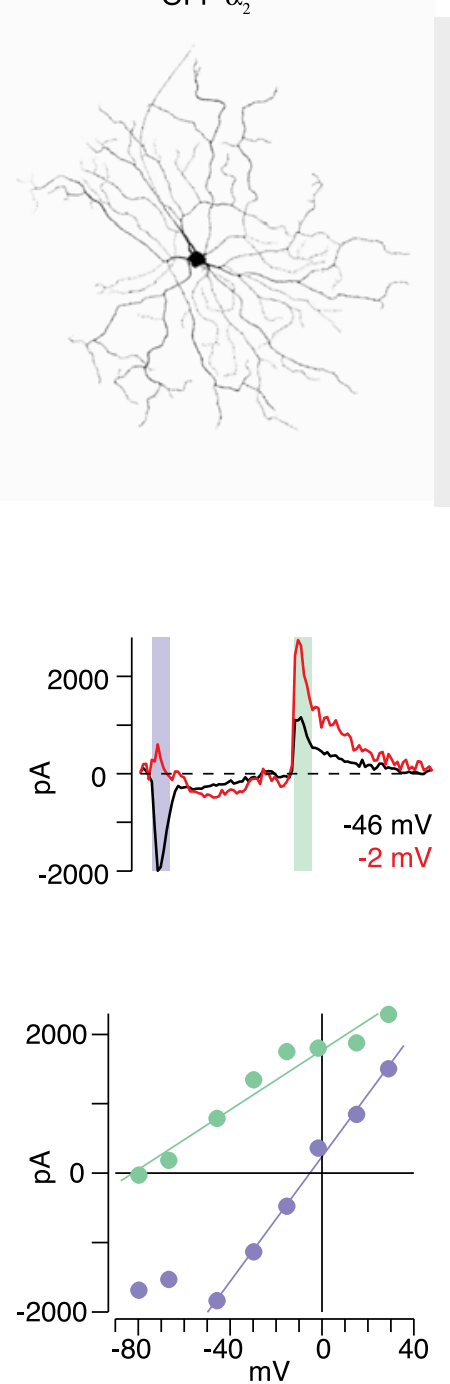

OFF $\delta$
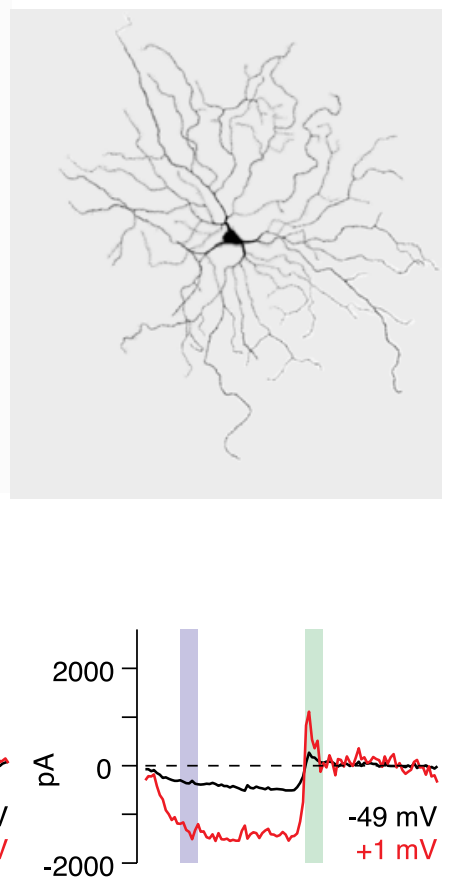

Figure 3. Physiological properties of ganglion cells with large somas in guinea pig retina. $A$, Filled cell body and dendritic tree for one $0 \mathrm{~N} \alpha$ cell, two $0 \mathrm{FF} \alpha$ cells, and one $0 \mathrm{FF} \delta$ cell. Dendritic field diameters (left to right) were 570,512,541, and $626 \mu \mathrm{m}$. Dendrite stratifications for the same cells were 30,71,71, and 90\%. B, Spot responses at different holding potentials $\left(V_{\text {hold }}\right)$ for cells in $\boldsymbol{A}$. C, I-V relationship for the cells in $\boldsymbol{B}$. The $0 \mathrm{~N}-\alpha / \mathrm{Y}$-cell response to the dark spot reversed at $-30 \mathrm{mV}$ (left; reversal to light spot, $-40 \mathrm{mV}$ ). Both 0 FF- $\alpha / Y$-cell responses to the dark spot reversed near the excitatory reversal $\left(E_{\text {excitation, }} \sim 0 \mathrm{mV}\right.$ ), but one cell ( $\left.0 \mathrm{FF} \alpha_{1}\right)$ showed a relatively linear conductance, whereas the other $\left(0 \mathrm{FF} \alpha_{2}\right)$ showed a pronounced J-shaped conductance. In the $0 \mathrm{FF}$ $\delta$ cell, responses to both light and dark spots reversed near $E_{\mathrm{CI}}(-70$ and $-74 \mathrm{mV}$, respectively), suggesting that contrast processing arises primarily from modulation of an inhibitory synapse.

level (see Materials and Methods). However, there was variability in the degree to which the reversal was positive to $0 \mathrm{mV}$; in some cases, the reversal was close to $0 \mathrm{mV}$ (Fig. $5 B$ ).

To quantify further the above results, we fit each $I-V$ plot with the sum of two underlying conductances reversing at 0 and -67 $\mathrm{mV}$ (see Materials and Methods). This conductance analysis calculates the relative contribution from excitatory and inhibitory synapses. The conductance analysis showed that ON cells received increased excitation and inhibition, in parallel, at all contrasts (Fig. 5C). OFF cells received increased excitation in parallel with decreased inhibition (i.e., disinhibition) at all contrasts. However, disinhibition played a relatively prominent role at low contrasts (Fig. 5C). For example, at $2.5 \%$ contrast, the decreased inhibitory conductance was $-0.55 \pm 0.06 \mathrm{nS}$, which was greater in magnitude than the increased excitatory conductance of $0.23 \pm 0.03 \mathrm{nS}$ (difference of $0.32 \pm 0.05 \mathrm{nS} ; n=38 ; p<0.001$ ). Similarly, at $5 \%$ contrast, the decreased inhibitory conductance was $-1.50 \pm 0.16 \mathrm{nS}$, which was greater in magnitude than the increased excitatory conductance of $0.84 \pm 0.12 \mathrm{nS}$ (difference of
$0.66 \pm 0.14 \mathrm{nS} ; n=38 ; p<0.001)$. At $10 \%$ contrast, the decreased inhibitory conductance $(-3.3 \pm 0.3 \mathrm{nS})$ and the increased excitatory conductance $(2.9 \pm 0.4 \mathrm{nS})$ were of similar magnitude (difference of $0.4 \pm 0.4 \mathrm{nS} ; n=38 ; p>0.2$ ). In Discussion, we consider how these two conductances would contribute to low-contrast voltage responses, given the expected resting potential and reversal potentials for excitation and inhibition in situ.

OFF cell responses to high contrast $(80 \%)$ were dominated by an increased excitatory conductance. Some cells showed a linear conductance (Figs. 5B, 6D), whereas others showed a nonlinear, J-shaped conductance, indicating an NMDA receptor contribution (Fig. $7 A, C$ ) (see also Fig. $3 C$ ). To estimate the full AMPA plus NMDA conductance, we performed the conductance analysis on data collected for $V_{\text {hold }}$ values positive to $-40 \mathrm{mV}$, at which the nonlinearity associated with NMDA receptors has minimal effect (see Materials and Methods). At $80 \%$ contrast, the magnitude of the decreased inhibitory conductance was relatively small $(-2.7 \pm 0.6 \mathrm{nS})$ compared with the excitatory conductance $(17.9 \pm 2.4 \mathrm{nS} ; n=21)$. 
A
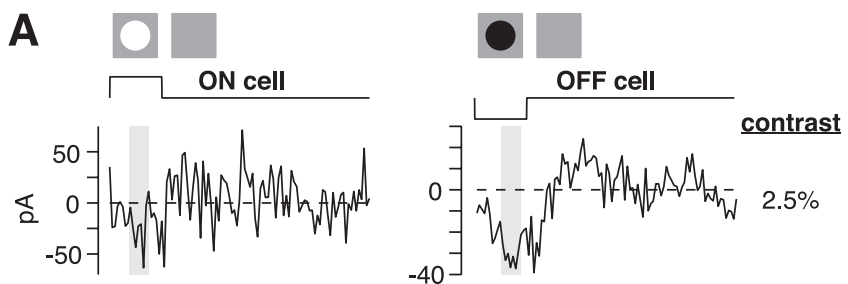

至 $00-1$ -
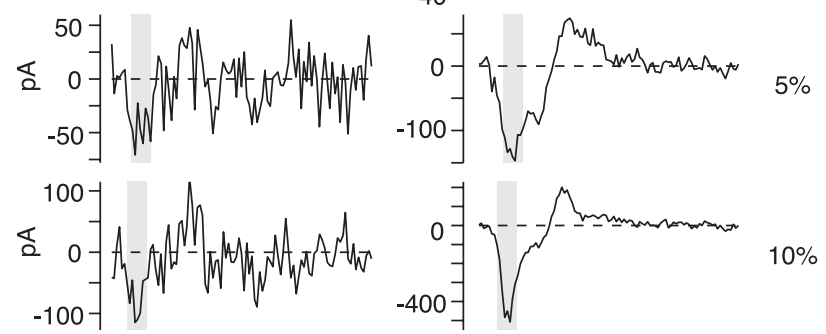

$10 \%$
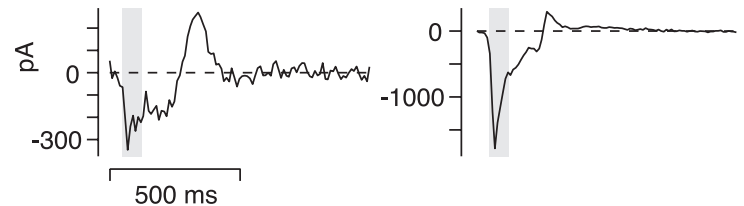

$80 \%$

\section{B}
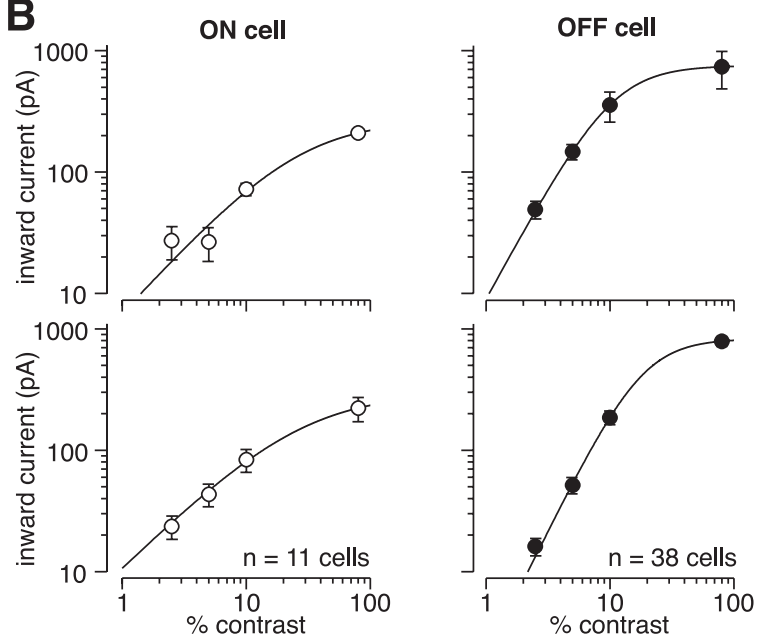

Figure 4. Membrane current responses at low and high contrast. A, An OFF or ON cell was stimulated with a $200 \mathrm{~ms}$ spot ( $0.6 \mathrm{~mm}$ diameter) over the receptive field center at $2.5,5,10$, or $80 \%$ contrast. Contrast is defined as an increment (ON cells) or decrement (OFF cells) in the mean luminance. Voltage was held near the resting potential $\left(V_{\text {rest }}\right)$ (see Materials and Methods). Shaded area shows the sampling window for measuring current amplitude in $\boldsymbol{B}$. Traces show an average across $6-12$ cycles. $\boldsymbol{B}$, Top row, Contrast-response functions for the cells in $\boldsymbol{A}$. Points show average inward current at each contrast $\left(V_{\text {hold }}\right.$ near $\left.V_{\text {rest }}\right)$. Error bars show SEM of response across cycles. Line is a fit to the data (see Materials and Methods). $0 \mathrm{~N}$ cell parameters: $R_{\text {max }}, 170 ; c_{50}, 9.3 ; n, 1.0$. OFF cell parameters: $R_{\text {max }}, 750 ; c_{50}, 11 ; n, 1.9$. Bottom row, Average inward current as a function of contrast across cells. Error bars show $S E M$ across cells. Population ON cell parameters: $R_{\text {max }}, 330 ; c_{50}, 29 ; n, 1.0$. Population OFF cell parameters: $R_{\text {max }} 830 ; c_{50}, 18$; $n, 2.1$.

\section{The OFF cell disinhibition circuit is driven by the ON pathway}

The above results suggest that contrast responses in an OFF ganglion cell are driven partly by removing synaptic inhibition (i.e., disinhibition). It follows that the disinhibition would be driven by the ON pathway: light decrement would hyperpolarize ON bipolar cells and consequently hyperpolarize downstream inhibitory amacrine cells that synapse on the OFF ganglion cell. To test this idea, we suppressed the ON pathway using the mGluR6 agonist L-AP-4, which continually activates the ON bipolar cell mGluR6 cascade resulting in cation channel closure and hyper-
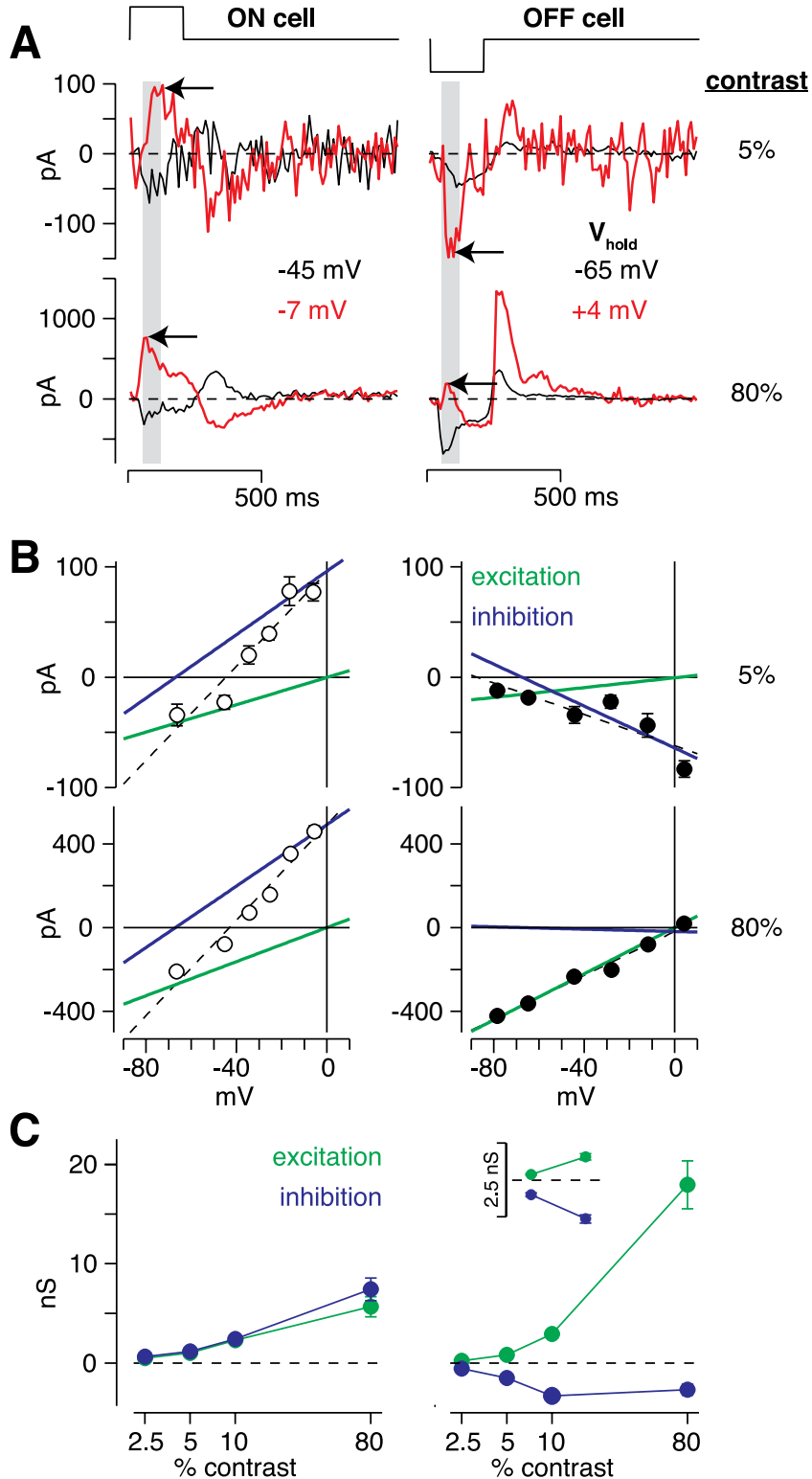

$80 \%$

Figure 5. OFF cell contrast responses are driven in part by disinhibition. $\boldsymbol{A}$, Flash responses at different holding potentials $\left(V_{\text {hold }}\right)$. In the $0 \mathrm{~N}$ cell, low- and high-contrast flashes both elicited an inward current near rest and an outward current near the excitatory reversal (red; $E_{\text {excitation }}$ $\sim 0 \mathrm{mV}$; arrows). In the OFF cell, low- and high-contrast flashes both elicited an inward current near the resting potential. Holding the cell near $E_{\text {excitation }}$ elicited an inward current at low contrast but an outward current at high contrast (arrows). $\boldsymbol{B}, I-V$ relationship for the cells in $\boldsymbol{A}$. The $0 \mathrm{~N}$ cell responses to low (5\%) and high contrast $(80 \%)$ had similar reversals (low contrast, $-44 \mathrm{mV}$; high contrast, $-43 \mathrm{mV}$ ) and proportional increases in excitatory and inhibitory conductance (green and blue lines, respectively). Dashed lines are linear fits to the data. The low-contrast response in the OFF cell reversed at $-90 \mathrm{mV}$ and predominantly comprised removal of an inhibitory conductance and a minor excitatory conductance. The opposite was true at high contrast, at which the response reversed at $+4 \mathrm{mV}$ and was primarily caused by an excitatory conductance. C, Comparison of excitatory and inhibitory conductances. For ON cells, excitation and inhibition increased in parallel with increasing contrast $(n=11)$. For OFF cell low-contrast responses (2.5-10\%), disinhibition contributed substantially $(n=38)$, whereas for high-contrast responses, excitation dominated ( $n=21)$; inset shows conductances for the 2.5 and $5 \%$ contrast responses on an expanded scale.

polarization (Slaughter and Miller, 1981; Nakajima et al., 1993). At $50 \mu \mathrm{M}, \mathrm{L}-\mathrm{AP}-4$ completely suppressed the response of an ON ganglion cell to a high-contrast reversing spot $(n=2$ cells) (same stimulus used in Fig. 3), suggesting that the presynaptic ON bipolar cells were completely inhibited at this concentration (Fig. 

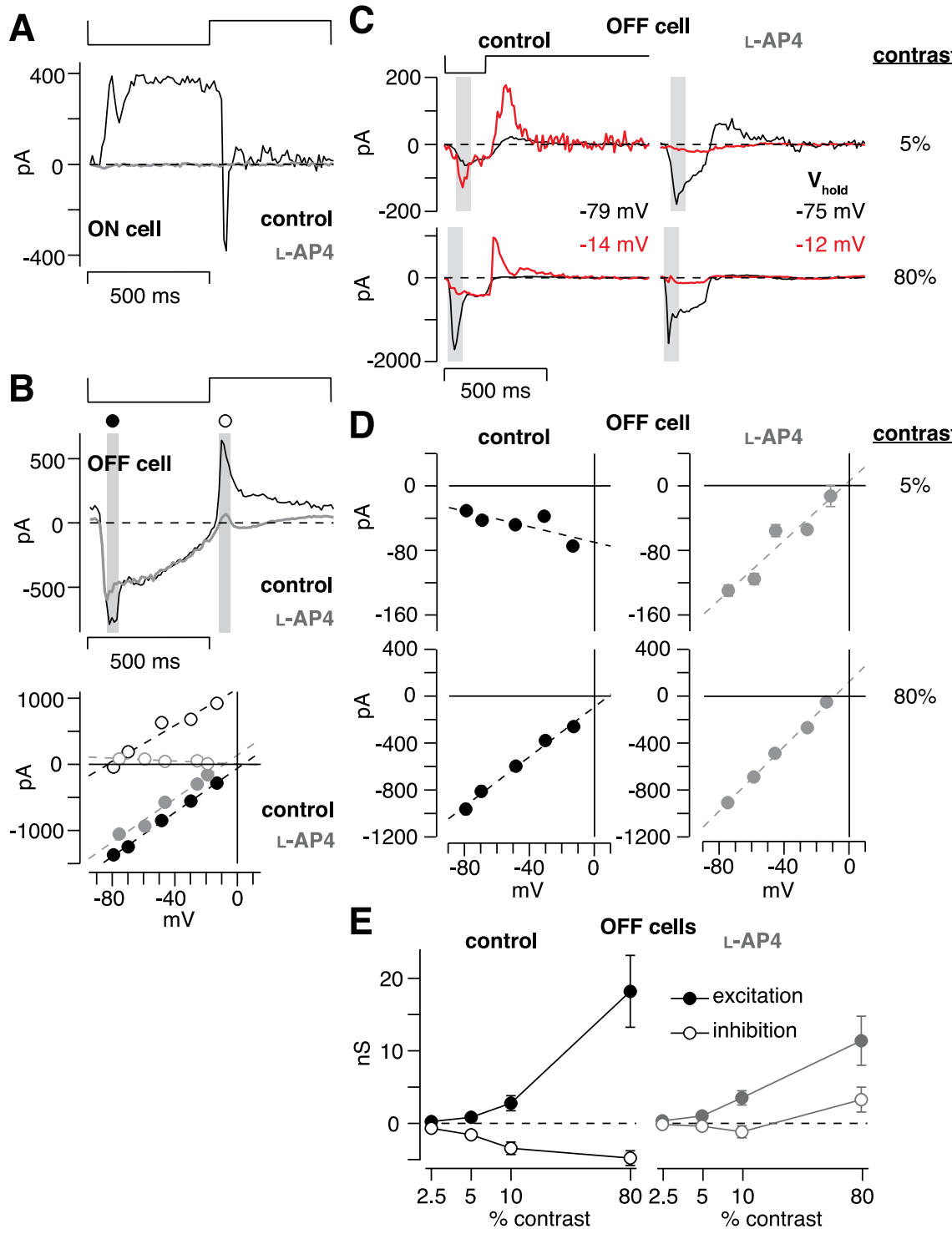

Figure 6. The $0 \mathrm{~N}$ pathway mediates disinhibition in $0 \mathrm{FF}$ cells. $A$, An $\mathrm{ON}$ cell was stimulated with a contrast-reversing spot $(100 \%$ contrast, $1 \mathrm{~Hz})$. Under control conditions (black; $V_{\text {hold }}$ of $\left.-45 \mathrm{mV}\right)$, the cell responded to dark with an outward current and to light with a transient inward current. Bath-applied $50 \mu \mathrm{ML}-\mathrm{AP}-4$ blocked the response (gray; $V_{\text {hold }}$ of $-60 \mathrm{mV}$ ). $\boldsymbol{B}$, An OFF cell was stimulated with the spot described in $A$. The cell responded to dark with an inward current and to light with an outward current; $50 \mu \mathrm{m} \mathrm{L-AP-4}$ blocked the outward current (top; control, $V_{\text {hold }}$ of $-69 \mathrm{mV}$; L-AP-4, $V_{\text {hold }}$ of $-59 \mathrm{mV}$ ). The $I-V$ plot (bottom) shows a positive conductance after the dark spot (filled circles) during control (black; reversal potential, $+4 \mathrm{mV}$ ) and L-AP-4 conditions (gray; reversal potential, $-8 \mathrm{mV}$ ). The light spot (white circles) elicited a large inhibitory conductance under control conditions (reversal potential, $-82 \mathrm{mV}$ ) and a small withdrawal of an excitatory conductance in the presence of L-AP-4 (gray; reversal potential, $+3 \mathrm{mV}$ ). C, Flash responses in an $0 \mathrm{FF}$ cell at different holding potentials under control conditions and in the presence of I-AP-4. D, I-V plots for the cell in C. At 5\% contrast, there was a negative conductance under control conditions that reversed to a positive conductance in the presence of L-AP-4. Adding L-AP-4 had minimal effect on the $80 \%$ contrast conductance. $\boldsymbol{E}$, Summary of the results in $\boldsymbol{D}$ across OFF cells. Excitation slightly increased in the presence of L-AP-4 (gray circles) versus control conditions (black circles), but the inhibitory components of the response decreased in the presence of L-AP-4 (white circles; $n=10$ cells for $2.5-10 \%$ contrast). At $80 \%$ contrast, there was an increased inhibitory conductance in the presence of L-AP-4, suggesting an unmasked feedforward inhibition ( $n=8$ cells).

$6 A)$. In OFF ganglion cells, L-AP-4 did not suppress the inward current to the dark phase of the reversing spot (100\% contrast), which is presumably driven primarily by OFF bipolar cells, but did suppress the outward current to the light phase (control, $357 \pm 75$ pA; L-AP-4, $0.6 \pm 22.2 \mathrm{pA} ; n=10$ cells; $p<0.001$; average $\pm \mathrm{SD} V_{\text {hold }},-54 \pm 5 \mathrm{mV}$ ) (Fig. $6 \mathrm{~B}$ ). This confirms previous work showing that, for OFF ganglion cells, the ON pathway drives an inhibitory conductance at light onset (Wassle et al.,
1986; Cohen, 1998; Pang et al., 2003; Zaghloul et al., 2003; Murphy and Rieke, 2006; Roska et al., 2006).

We next tested whether the ON pathway drives OFF cell low-contrast responses to light offset, using the $200 \mathrm{~ms}$ decrement stimulus (Fig. 6C). At low contrast, there was a decreased conductance, as indicated by negative slopes on the $I-V$ plots (Fig. $6 D)$. In the presence of L-AP-4, these negative slopes became positive, suggesting that the disinhibition pathway was blocked. At high contrast (80\%), there were positive slopes in both control and L-AP-4 conditions (Fig. 6D). We performed a conductance analysis, as described above. L-AP-4 significantly reduced the magnitude of the decreased inhibitory conductance ( $p<0.05$ at each contrast) but did not block the increased excitatory conductance (Fig. 6E). These data suggest that disinhibition of OFF cells is driven by ON-pathway amacrine cell synapses.

In addition to blocking the decreased inhibitory conductance, L-AP-4 revealed an increased inhibitory conductance at $80 \%$ contrast (Fig. 6E). Across cells, this conductance was $3.4 \pm 1.8 \mathrm{nS}(n=8)$. This inhibitory conductance may be present at high contrast under control conditions but masked by the decreased inhibitory conductance. This suggests that a feedforward inhibitory synapse, driven by the OFF pathway, acts in parallel with OFF bipolar cell excitation. However, this putative feedforward inhibition requires additional characterization. For example, our conclusion depends on a slight shift in the reversal potential (Fig. 6D). Furthermore, in the presence of L-AP-4, inhibition of the OFF bipolar terminal is presumably reduced, and thus the output of OFF bipolar cells would increase, potentially altering the degree of feedforward inhibition present under natural conditions.

\section{The disinhibition circuit does not} require ionotropic glutamate receptors Virtually every circuit, from photoreceptors to amacrine or ganglion cells in the inner retina, requires at least one synapse mediated by an iGluR (Marc, 1999a,b; Kalloniatis et al., 2004; Dumitrescu et al., 2006). The one known exception is the following circuit: cone $\rightarrow$ ON cone bipolar cell $\rightarrow$ AII amacrine cell $\rightarrow$ OFF ganglion cell (see Introduction); rods could also drive this circuit through their gap junctions with cones. The cone $\rightarrow$ ON cone bipolar synapse uses an mGluR6 receptor (Nakajima et al., 1993; Nomura et al., 1994); the ON cone bipolar $\rightarrow$ AII amacrine cell synapse uses a connexin (cx) 36 gap junction or a cx36/cx45 gap junction (Feigenspan et al., 2001; Mills et al., 2001; Deans et al., 2002; Han and Massey, 2005; Lin et al., 2005); the AII amacrine cell $\rightarrow$ OFF ganglion cell synapse uses 


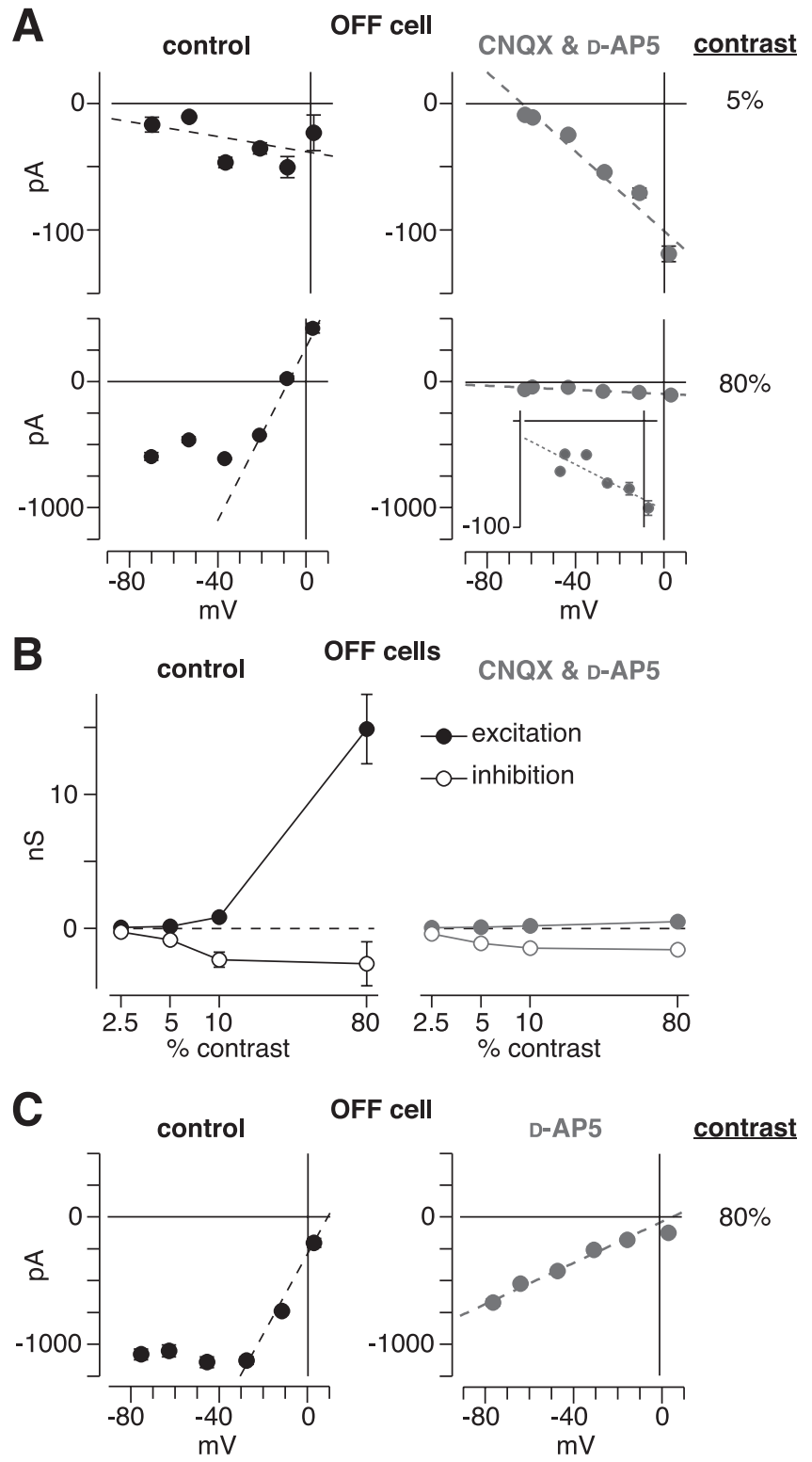

Figure 7. Disinhibition of OFF ganglion cells does not require ionotropic glutamate receptors. A, I-V plot for low- and high-contrast responses in an OFF cell (same conventions as for Fig. $5 B$ ). Under control conditions, there was a negative conductance at $5 \%$ contrast and a positive conductance at $80 \%$ contrast with an apparent NMDA component, resulting in a J-shaped function. In the presence of CNQX and D-AP-5 (100 $\mu \mathrm{m}$ each), the 5\% response persisted, whereas the $80 \%$ response was primarily blocked. Inset, The persisting response at $80 \%$ contrast had a negative slope, similar to the $5 \%$ response. $\boldsymbol{B}$, Conductance analysis under control conditions and in the presence of CNQX plus D-AP-5 (same conventions as for Fig. 5C). The drugs primarily blocked the excitatory component, leaving disinhibition intact. C, Same format as in $\boldsymbol{A}$ for an OFF cell, in which D-AP-5 was applied alone.

a glycine receptor (Muller et al., 1988; Sassoe-Pognetto et al., 1994; Murphy and Rieke, 2006). Thus, if this circuit explains ON pathway disinhibition of OFF ganglion cells, then it should persist in the presence of iGluR antagonists.

To test the above possibility, we measured responses while blocking both AMPA/kainate and NMDA receptors with CNQX $(100 \mu \mathrm{M})$ and D-AP-5 (100 $\mu \mathrm{M})$ (Cohen et al., 1994; Cohen, 1998; Cohen and Miller, 1999). In the presence of these antagonists, low-contrast responses persisted, and these responses were driven primarily by disinhibition (Fig. 7B). However, highcontrast responses were suppressed; the inward current de- creased from $-399 \pm 37 \mathrm{pA}$ under control conditions to $-59 \pm$ $16 \mathrm{pA}$ in the presence of the antagonists (decrease of $86 \pm 3 \%$, $p<0.001 ; n=6$ cells; $V_{\text {hold }}$ near the $\left.V_{\text {rest }}\right)$. Furthermore, in the presence of the antagonists, the conductance at high contrast showed a negative slope, similar to the low-contrast conductance (Fig. 7A). Blocking NMDA receptors alone with D-AP-5 (50 $\mu \mathrm{M})$ made the J-shaped $I-V$ plot more linear but did not completely block excitatory currents at high contrast (Fig. 7C). Thus, we conclude that disinhibition of OFF cells, at low and high contrast, could originate in the above described AII amacrine cell pathway.

The above response cannot, however, be driven by two of the rod pathways. Rods release glutamate onto OFF cone bipolar cell dendrites, but these dendrites express iGluRs (Soucy et al., 1998; Hack et al., 1999; Tsukamoto et al., 2001; Li et al., 2004). Furthermore, the rod pathway illustrated in Figure $1 A$ uses an iGluR at the rod bipolar $\rightarrow$ AII cell synapse (Boos et al., 1993; Singer and Diamond, 2003). Rods can signal cones directly, through gap junctions (DeVries and Baylor, 1995; Bloomfield and Dacheux, 2001). These rod signals could reach ganglion cells through cone synapses with ON cone bipolar cells and then through the AII circuit (i.e., rod $\rightarrow$ cone $\rightarrow$ ON cone bipolar $\rightarrow$ AII cell $\rightarrow$ ganglion cell). However, rod signals could not reach ganglion cells through cone synapses with OFF cone bipolar cells, because the cones release onto iGluRs on the bipolar cell (Fig. $1 B$ ).

\section{Evidence that the disinhibition circuit includes the AII amacrine cell}

To test the role of the above AII circuit in OFF ganglion cell disinhibition, we performed several experiments designed to disrupt each synapse in the circuit. We first isolated the putative circuit by blocking iGluRs with D-AP-5 $(200 \mu \mathrm{M})$ and CNQX $(200 \mu \mathrm{M})$ (Fig. $8 \mathrm{~A}$ ) and then measured the $10 \%$ contrast response before and after adding additional drugs ( $V_{\text {hold }}$ of -35 to -25 $\mathrm{mV}$ ) (Fig. $8 \mathrm{~A}$ ). In one experiment, we added L-AP-4, to confirm that the response was driven by the ON pathway (cone $\rightarrow$ ON cone bipolar synapse), as suggested by the results in Figure 6 (Fig. $\left.8 A_{1}\right)$. The inward current in the presence of CNQX and D-AP-5 $(-37.0 \pm 17.3 \mathrm{pA})$ was significantly reduced by adding L-AP-4 $(+1.6 \pm 2.0 \mathrm{pA} ; p<0.05 ; n=6)$. During a washout of all drugs, the response partially recovered to $-23 \pm 9 \mathrm{pA}$ (compared with an initial response of $-57 \pm 27 \mathrm{pA} ; n=4$ ).

We next tested a role for a gap junction at the ON cone bipolar $\rightarrow$ AII amacrine cell synapse (Feigenspan et al., 2001; Mills et al., 2001; Deans et al., 2002; Lee et al., 2003a; Han and Massey, 2005). To test this, we applied meclofenamic acid (MFA) (200 $\mu \mathrm{M})$, which blocks tracer coupling between AII cells and ON cone bipolar cells (Pan et al., 2007). The inward current in the presence of CNQX and D-AP-5 $(-127 \pm 9 \mathrm{pA})$ was significantly reduced by adding MFA $(-46 \pm 11 \mathrm{pA} ; p<0.01 ; n=6)$. We measured a recovery, after washing out all drugs, in two cases; one is shown in Figure $8 A_{2}$. In another set of experiments, we applied quinine $(200 \mu \mathrm{M})$, which blocks cx36 gap junctions (Srinivas et al., 2001; Schubert et al., 2005). The inward current in the presence of CNQX and D-AP-5 $(-52.2 \pm 13.9 \mathrm{pA})$ was significantly reduced by adding quinine $(-12.9 \pm 3.4 \mathrm{pA} ; p<0.05 ; n=6)$. The response partially recovered after washing out all drugs to $-39 \pm$ $22 \mathrm{pA}$ (compared with initial response of $-50 \pm 16 \mathrm{pA} ; n=4$ ) (Fig. $8 A_{3}$ ). Quinine can also block potassium channels, and so as a control we repeated the above experiment but applied potassium channel blockers (1 mM TEA and $1 \mathrm{~mm} 4$-AP) in place of quinine (Imai et al., 1999). The inward current in the presence of CNQX and D-AP-5 $(-134 \pm 35 \mathrm{pA})$ was not 


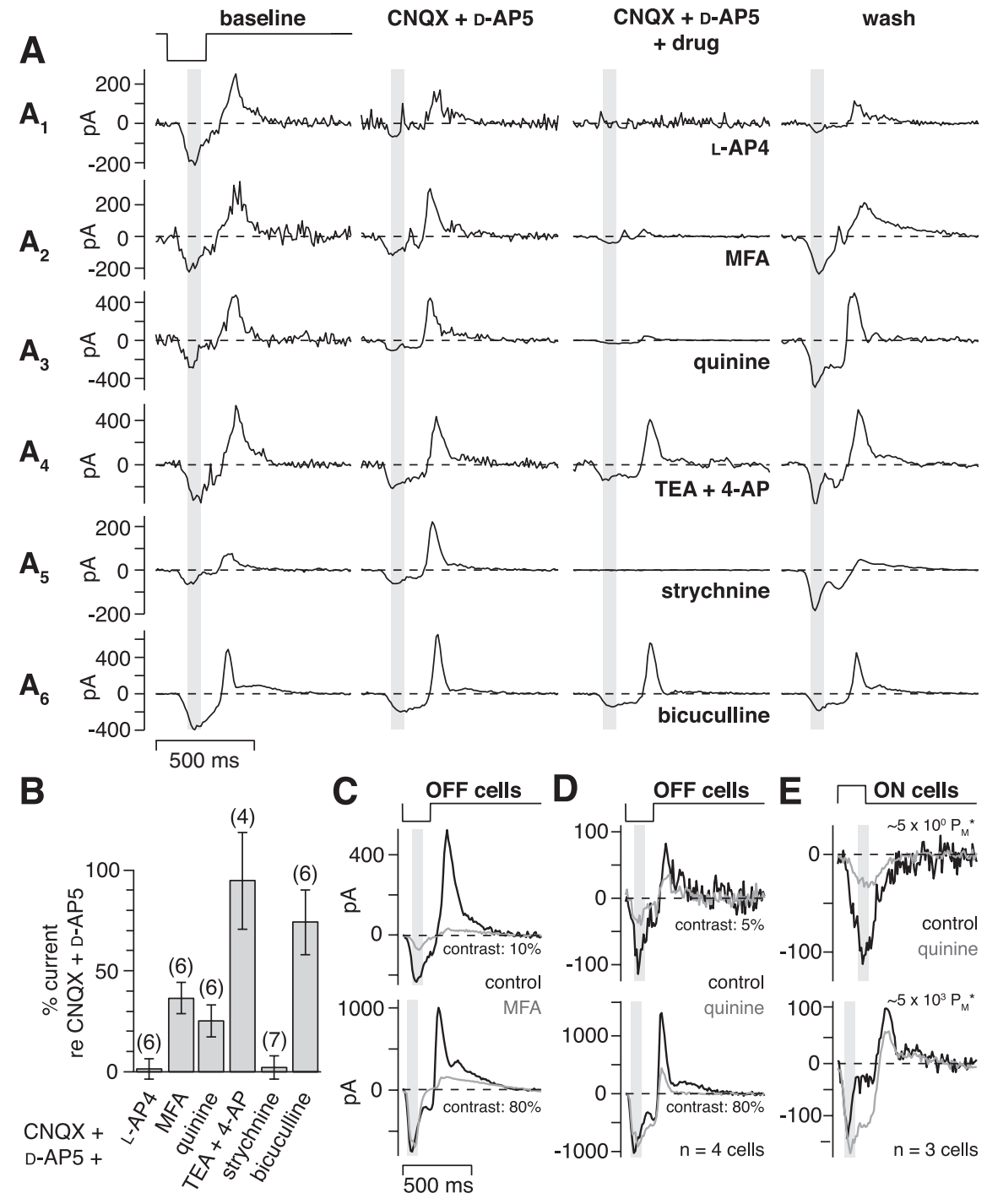

Figure 8. Evidence that the disinhibition circuit uses the All amacrine cell. $A$, Six 0 FF cells were stimulated with repeating dark flashes (contrast, $10 \%$; $V_{\text {hold }}$ approximately -35 to $-25 \mathrm{mV}$ ) under baseline conditions, with bath-applied drugs, and after washing out the drugs. Adding L-AP-4 $\left(A_{1}, 100 \mu \mathrm{M}\right)$, MFA $\left(A_{2}, 200 \mu \mathrm{M}\right)$, quinine $\left(\boldsymbol{A}_{3}, 200 \mu \mathrm{M}\right)$, or strychnine $\left(\boldsymbol{A}_{5}, 2 \mu \mathrm{M}\right)$ to CNQX $(200 \mu \mathrm{M})$ and D-AP-5 $(200 \mu \mathrm{M})$ sharply reduced the current responses to the flash, whereas adding bicuculline $\left(A_{6}, 100 \mu \mathrm{M}\right)$ or TEA and 4-AP $\left(\boldsymbol{A}_{4}, 1 \mathrm{~mm}\right.$ each) had little effect. $\boldsymbol{B}$, Results for the experiment in $\boldsymbol{A}$ across multiple cells (number of cells in parentheses). The bars show the inward current elicited by the $10 \%$ contrast flash in each drug condition (CNQX and D-AP-5, plus the drug on the $x$-axis) relative to the inward current in the presence of CNQX and D-AP-5 alone. Adding L-AP-4, meclofenamic acid, quinine, or strychnine decreased the inward current to a small percentage of the original current. Adding bicuculline or TEA and 4-AP had little effect (see Results). Error bars indicate SEM across cells. C, Meclofenamic acid (200 $\mu \mathrm{M}$ ) applied alone reduced the $10 \%$ contrast response and also reduced the outward current at the offset of $80 \%$ contrast. The inward current at high contrast was unaffected, suggesting no general depression of OFF bipolar cells. Traces show the average response of five to six cells. $\boldsymbol{D}$, Quinine $(200 \mu \mathrm{M})$ applied alone produced results similar to $C$, reducing the $5 \%$ contrast response and also reducing the outward current at the offset of $80 \%$ contrast. The inward current at high contrast was unaffected. Traces show the average of recordings from four cells. $E, 0 N$ cells were stimulated with repeating bright flashes (contrast, $100 \% ; 20$ repeats; $V_{\text {hold }}$ approximately -63 $\mathrm{mV}$ ) at two levels of mean luminance. Quinine suppressed the inward current only under rod-bipolar-driven conditions $(\sim 5 \times$ $\left.10^{\circ} \mathrm{P}_{\mathrm{M}}^{*}\right)$. Traces show the average of recordings from three cells.

blocked by adding TEA and 4-AP $(-113 \pm 31 \mathrm{pA} ; p>0.10$; $n=4)$, suggesting that quinine did not act by blocking potassium channels (Fig. $8 \mathrm{~A}_{4}$ ). Additional control experiments for MFA and quinine are described in a separate section below.

We next tested roles for glycine and GABA. Glycine receptors were blocked with strychnine $(2 \mu \mathrm{M})$. The inward current in the presence of CNQX and D-AP-5 $(-31.9 \pm 4.2 \mathrm{pA})$ was completely blocked by adding strychnine $(-0.1 \pm 1.4 \mathrm{pA} ; p<0.05 ; n=7)$. In general, it was difficult to measure recovery after strychnine application, although we were able to measure partial recovery in two cells; one is shown in Figure $8 A_{5}$. In separate experiments, we blocked $\mathrm{GABA}_{\mathrm{A}}$ receptors with bicuculline $(100 \mu \mathrm{M})$. The response in the presence of CNQX and D-AP-5 (-93.0 \pm $19.2 \mathrm{pA}$ ) was only slightly suppressed by adding bicuculline $(-69.5 \pm 18.8 \mathrm{pA} ; n=$ 6) (Fig. $8 A_{6}$ ).

The above results are summarized in Figure $8 \mathrm{~B}$. The inward current response at $10 \%$ contrast showed, relative to the recording in the presence of D-AP-5 and CNQX, a significant percent reduction after adding L-AP-4 (99 $\pm 5 \%$; $p<0.001)$, MFA $(64 \pm 8 \% ; p<0.01)$, quinine $(75 \pm$ $8 \% ; p<0.001)$, or strychnine (98 $\pm 6 \%$; $p<0.001)$ but not after adding TEA and 4 -AP $(5 \pm 24 \%$; $p>0.10)$ or bicuculline (26 $\pm 16 \% ; p>0.05)$. The small effect of bicuculline could be explained by nonspecific effects of bicuculline on glycine receptors (Wang and Slaughter, 2005). These results suggest that the disinhibition circuit for OFF ganglion cells depends on mGluR6 receptors, gap junctions, and glycine receptors. These results can be explained most parsimoniously by the above-described circuit: $($ rod $\rightarrow$ ) cone $\rightarrow$ ON cone bipolar cell $\rightarrow$ AII amacrine cell $\rightarrow$ OFF ganglion cell (Fig. $1 B$ ).

Control experiments further suggest that MFA and quinine block the gap junction between AII cells and ON cone bipolar cells

We performed additional experiments to test whether MFA or quinine had unexpected, nonspecific effects on retinal processing, similar to other gap junction blockers (Xia and Nawy, 2003). In OFF cells $\left(n=6\right.$; $V_{\text {hold }},-20$ to $\left.-35 \mathrm{mV}\right)$, applying MFA in isolation did not affect the inward current at $80 \%$ contrast (control, $-591 \pm 88 \mathrm{pA}$; MFA, $-601 \pm 126 \mathrm{pA} ; p>$ 0.4 ) but did reduce the outward rebound current (control, $+629 \pm 131 \mathrm{pA}$; MFA, $+72 \pm 32 \mathrm{pA})$ by $557 \pm 128 \mathrm{pA}(p<0.01)$ (Fig. $8 C$ ). Furthermore, MFA reduced the inward current at $10 \%$ contrast (control, $-209 \pm 23 \mathrm{pA}$; MFA, $-47 \pm 18 \mathrm{pA})$ by $162 \pm 34 \mathrm{pA}(p<0.01)$ (Fig. $8 C)$. In additional experiments on OFF cells $(n=4$; $V_{\text {hold }},-29$ to $-36 \mathrm{mV}$ ), applying quinine in isolation did not affect the inward current at $80 \%$ contrast (control, $-804 \pm 97 \mathrm{pA}$; quinine, $-775 \pm 156 \mathrm{pA} ; p>0.4$ ) but did reduce the outward rebound current (control, $+747 \pm 83$ pA; quinine, $+140 \pm 20$ pA) by $606 \pm 97 \mathrm{pA}(p<0.01)$ (Fig. $8 D)$. Furthermore, quinine reduced the inward current at $5 \%$ contrast (control, $-77 \pm 15 \mathrm{pA}$; quinine, $-29 \pm 8 \mathrm{pA}$ ) by $48 \pm 9 \mathrm{pA}(p<0.05)$ (Fig. $8 D)$. The above results suggest that MFA and quinine interrupt the cone $\rightarrow$ ON cone bipolar $\rightarrow$ AII amacrine cell $\rightarrow$ OFF ganglion cell circuit, presumably by 
blocking the ON bipolar $\rightarrow$ AII cell synapse. The rebound current at high contrast would be driven, at light onset (i.e., dark spot offset), by stimulating the AII circuit (Fig. 6B). The inward current at low contrast would be driven in large part by disinhibition from the AII circuit, as described above.

We performed additional control experiments in ON cells ( $n=3$; $V_{\text {hold }},-63$ to $-64 \mathrm{mV}$ ). If quinine blocks the $\mathrm{ON}$ cone bipolar cell $\rightarrow$ AII cell gap junction, then ON ganglion cell responses should decrease under conditions that depend heavily on the rod bipolar pathway but persist under conditions driven by the cone bipolar pathway (Fig. 1). Under rod-driven conditions, the inward current to the flash decreased from $-126 \pm 49 \mathrm{pA}$ (control) to $-29 \pm 13$ $\mathrm{pA}$ in the presence of quinine (a difference of $97 \pm 37 \mathrm{pA} ; p<0.10)$. At cone-driven levels, however, the inward current was similar across conditions (control, $-103 \pm$ $31 \mathrm{pA}$; quinine, $-109 \pm 34 \mathrm{pA} ; p>0.4$ ) (Fig. $8 E$ ). This result suggests that quinine inhibits the ON cone bipolar $\rightarrow$ AII cell synapse. There were other effects of quinine that we cannot explain, such as the more sustained inward current for ON cells at high mean luminance (Fig. 8 E). Gap junctions exist at several sites in the retina, including the rod $\rightarrow$ cone gap junction (Deans et al., 2002; Lee et al., 2003b) and ganglion cell $\rightarrow$ amacrine cell gap junctions (Schubert et al., 2005; Volgyi et al., 2005); thus, some effects of quinine could be explained by actions at these alternative sites. However, these control experiments are generally consistent with an effect of MFA or quinine at the $\mathrm{ON}$ cone bipolar $\rightarrow$ AII cell synapse.

\section{Disinhibition from the putative AII amacrine cell circuit drives OFF ganglion cell responses under conditions driven by both cone and rod bipolar cells}

Above, we assumed that AII cells synapse directly onto OFF ganglion cell dendrites. To test this, we measured responses at lower levels of mean luminance (Fig. 9). At all light levels, the rods should be active (i.e., not saturated) (Yin et al., 2006). At the higher levels, rods would contribute primarily through their gap junctions with cones, whereas at the lowest levels, the rod bipolar cell should be active and the AII circuit should become a dominant mechanism for light responses (Kolb and Famiglietti, 1974; Bloomfield and Dacheux, 2001; Deans et al., 2002) (Fig. 1A). Thus, at the lower levels of mean luminance, the conductance analysis should reflect the switch to the AII circuit. We measured $I-V$ plots for $100 \%$ contrast responses at four levels of mean luminance $\left(n=3\right.$ OFF cells). At high mean luminance $\left(\sim 5 \times 10^{3}\right.$ $\mathrm{P}_{\mathrm{M}}{ }^{\star}$ ) (see Materials and Methods), the initial response to the flash showed an increased conductance with a J-shaped $I-V$ plot, indicating a mixed AMPA/NMDA-mediated response $\left(\sim 5 \times 10^{2}\right.$ $\mathrm{P}_{\mathrm{M}}{ }^{*}$ : excitation, $33 \pm 3 \mathrm{nS}$, inhibition, $-1.9 \pm 0.7 \mathrm{nS} ; \sim 5 \times 10^{3}$ $\mathrm{P}_{\mathrm{M}}{ }^{\star}$ : excitation, $37 \pm 7 \mathrm{nS}$; inhibition, $\left.1.7 \pm 0.8 \mathrm{nS}\right)$. At lower mean luminance, however, the response to the flash showed a decreased conductance, consistent with a removal of inhibition from the AII circuit (Fig. 9B) $\left(5 \times \sim 10^{0} \mathrm{P}_{\mathrm{M}}{ }^{*}\right.$ : excitation, $1.7 \pm$ $0.4 \mathrm{nS}$; inhibition, $-6.1 \pm 0.2 \mathrm{nS} ; \sim 5 \times 10^{1} \mathrm{P}_{\mathrm{M}}^{*}$ : excitation, $3.2 \pm 0.4 \mathrm{nS}$; inhibition, $-7.6 \pm 0.4 \mathrm{nS})$. Thus, this putative AII circuit dominated the response at $\sim 5 \times 10^{0}-10^{1} \mathrm{P}_{\mathrm{M}}^{*}$, which was the apparent level of rod-dominated responses measured previously (Yin et al., 2006).

The sustained response to the $100 \%$ contrast flash at high mean luminance was also apparently driven by a distinct mechanism from the transient response (Fig. 9A) (see also Fig. $5 A)$. The sustained response also included disinhibition $\left(\sim 5 \times 10^{2} \mathrm{P}_{\mathrm{M}}^{*}\right.$ : excitation, $8.4 \pm 1.8 \mathrm{nS}$; inhibition, $-4.9 \pm$ $0.2 \mathrm{nS} ; \sim 5 \times 10^{3} \mathrm{P}_{\mathrm{M}}^{*}$; excitation, $6.1 \pm 1.7 \mathrm{nS}$; inhibition, $-5.2 \pm 0.7 \mathrm{nS})$, similar to the low-contrast response at high mean luminance (Figs. 5-7) and the high-contrast response at low mean luminance (Fig. 9B). Thus, at high mean luminance, the sustained high-contrast response, after the initial excitatory response attenuates, also apparently depends on the AII circuit.

At light onset (i.e., dark spot offset), there was an outward rebound current at each level of mean luminance that reversed near $E_{\mathrm{Cl}}$ (Fig. 9C). This rebound current is presumably caused, at 
least in part, by activating the AII circuit (see Discussion), and the circuit makes a similar contribution at all light levels. The inhibitory conductance at the two brighter levels $\left(\sim 5 \times 10^{2} \mathrm{P}_{\mathrm{M}}^{*}\right.$ : excitation, $0.2 \pm 0.7 \mathrm{nS}$; inhibition, $30 \pm 4 \mathrm{nS} ; \sim 5 \times 10^{3} \mathrm{P}_{\mathrm{M}}^{*}$; excitation, $0.7 \pm 0.7 \mathrm{nS}$; inhibition, $31 \pm 6 \mathrm{nS})$ was larger than that at the two dimmer levels $\left(\sim 5 \times 10^{0} \mathrm{P}_{\mathrm{M}}{ }^{*}\right.$ : excitation, $0.1 \pm$ $0.1 \mathrm{nS}$; inhibition, $5 \pm 2 \mathrm{nS} ; \sim 5 \times 10^{1} \mathrm{P}_{\mathrm{M}}{ }^{*}$ : excitation, $0 \pm 0.14$ $\mathrm{nS}$; inhibition, $14 \pm 1 \mathrm{nS}$ ). Still, it was remarkable that, across a $\sim 1000$-fold change in mean luminance, the inhibitory conductance varied by only $\sim 6$-fold.

\section{Discussion}

Figure $1 B$ illustrates our circuit model for contrast processing in the OFF ganglion cell under conditions driven by cone bipolar pathways. Responses are driven by a combination of excitation mediated by the OFF pathway and disinhibition mediated by the ON pathway. The disinhibition arises because a light decrement hyperpolarizes $\mathrm{ON}$ bipolar cells and electrically coupled AII amacrine cells; this latter hyperpolarization decreases glycine release onto the OFF ganglion cell. At low contrast, disinhibition plays a relatively large role, leading to an inward current at $V_{\text {rest }}$ associated with a negative conductance (Figs. 5-7, 9). At high contrast, disinhibition plays a smaller role, leading to an inward current at $V_{\text {rest }}$ associated with a positive conductance (Figs. 5-7, 9). At light onset (or dark offset), an inhibitory conductance is observed under conditions driven by either rod or cone bipolar pathways (Figs. $6 B, 8,9)$. This inhibition would arise from stimulating the AII circuit, which in turn inhibits the OFF ganglion cell. Thus, the AII circuit could explain crossover inhibition from ON to OFF pathways described previously (Zaghloul et al., 2003).

\section{Support for the circuit model for disinhibition of the OFF pathway}

The disinhibition circuit for OFF cells seems unconventional. Thus, it is worth reviewing evidence for each step in the pathway. First, ON bipolar cell responses should not be strongly rectifying, so they could signal either light increments or decrements to AII cells. Evidence for nonrectifying responses in ON bipolar cells comes from studies of ON ganglion cells. ON ganglion cells show excitatory responses that increase or decrease from a baseline level (Demb et al., 2001a; Zaghloul et al., 2003; Murphy and Rieke, 2006) (Fig. 3). Thus, ON bipolar cells apparently rest near the middle of their operating range and neither their voltage responses nor their glutamate release strongly rectify. Direct bipolar cell recordings support this interpretation (Dacey et al., 2000).

At the next step, current would flow from ON bipolar cells to AII cells. Depolarizing an ON bipolar cell causes depolarization of a coupled AII cell (Veruki and Hartveit, 2002; Trexler et al., 2005). Furthermore, AII cells responded to light under cone-driven conditions (Dacey, 1999; Xin and Bloomfield, 1999; Bloomfield and Dacheux, 2001; Pang et al., 2007). The apparent pathway mediating the cone-driven response is the following: cone $\rightarrow$ ON cone bipolar $\rightarrow$ AII cell. In support of this, AII light responses persist in the presence of an iGluR antagonist, which blocks the synaptic output of rod bipolar cells (Xin and Bloomfield, 1999; Trexler et al., 2005; Pang et al., 2007).

At the final step, the AII cell would directly synapse onto the OFF ganglion cell. Electron micrographs (EM) suggested that AII glycinergic outputs contact both OFF ganglion cell dendrites and their presynaptic OFF bipolar terminals (Famiglietti and Kolb,
1975; Kolb, 1979; Dacheux and Raviola, 1986). The relative number of these synapses has been estimated by serial section EM. In rat, at least $33 \%$ of chemical synaptic output from putative AII cells is onto ganglion cell dendrites (Chun et al., 1993). However, in rabbit, only $4 \%$ of output is onto ganglion cell dendrites (Strettoi et al., 1992). Recordings in mouse implied a strong output of AII cells onto OFF ganglion cell dendrites. At light levels at which rod bipolar cells are the primary conveyor of rod signals to the inner retina $\left(\sim 2 \mathrm{P}_{\mathrm{R}}{ }^{*}\right)$, an OFF $\alpha$ ganglion cell was driven primarily by an inhibitory glycinergic synapse (Murphy and Rieke, 2006); this glycinergic input is explained by the AII circuit (Murphy and Rieke, 2008). Thus, the dominant output of the mouse AII cell (driven by the rod bipolar cell) is onto the OFF ganglion cell dendrite. Our recordings at $\sim 10 \mathrm{P}_{\mathrm{R}}^{*}$ support this interpretation; the OFF ganglion cell response was primarily modulated by an inhibitory conductance (Fig. 9C). Furthermore, from the perspective of the OFF $\alpha$ ganglion cell (cat), the direct AII synapses are substantial: they are approximately equal in number to those from the OFF cone bipolar cells (Kolb and Nelson, 1993). Thus, there is strong evidence for a substantial input from AII cells to OFF ganglion cell dendrites in several species. The main exception is the EM study in rabbit, and this could reflect a species difference.

Our model suggests that disinhibition of an OFF ganglion cell is driven exclusively by AII cells. However, we cannot rule out a contribution from other narrow-field glycinergic amacrine cell types that could act in parallel with the AII cell (Menger et al., 1998). These other amacrine cell types would have to share certain features with the AII cell: excitation from ON bipolar cells and inhibitory synapses with the OFF $\alpha$ cell. However, the CNQX/D-AP-5-resistant response in the OFF ganglion cell is almost certainly explained exclusively by the AII circuit, because this is the only known pathway that can be driven by $\mathrm{ON}$ bipolar cells through gap junctions and thus does not require an iGluR in the circuit (Kolb, 1979; Cohen and Sterling, 1990). Because this CNQX/D-AP-5-resistant response explains the bulk of disinhibition (Figs. 7, 8), the AII circuit is likely the primary conveyor of disinhibition to the OFF ganglion cell.

\section{Rod and cone inputs to the AII circuit}

At the highest light level tested, responses are driven in approximately equal combination by rods and cones (Yin et al., 2006). At this level $\left(\sim 5 \times 10^{3} \mathrm{P}_{\mathrm{M}}{ }^{*}, \sim 10^{4} \mathrm{P}_{\mathrm{R}}{ }^{*}\right)$, rods likely act primarily through their electrical synapses with cones, assuming that the rod $\rightarrow$ rod bipolar pathway is saturated. We have not measured the level at which the rod bipolar saturates in guinea pig, but several lines of evidence suggest that cone bipolar pathways dominate at $\sim 10^{4} \mathrm{P}_{\mathrm{R}}{ }^{*}$. First, the excitatory response of OFF ganglion cells persists in the presence of L-AP-4, which would block the (ON-type) rod bipolar cell (Fig. 6B) (Zaghloul et al., 2003). Furthermore, inhibitory light responses in OFF ganglion cells persist in the presence of iGluR antagonists (Figs. 7, 8), and these must not depend on rod bipolar synapses (Fig. $1 \mathrm{~A}$ ). Thus, at $\sim 10^{4} \mathrm{P}_{\mathrm{R}}{ }^{*}$, rods apparently drive the proposed AII circuit that converges on the OFF ganglion cell, but this contribution must arise through their gap junctions with cones.

At the lowest light level tested here $\left(\sim 10 \mathrm{P}_{\mathrm{R}}^{*} ; \sim 5 \mathrm{P}_{\mathrm{M}}^{*}\right)$, the response is driven exclusively by rods (Yin et al., 2006). At this level, the OFF ganglion cell response to light offset (at high contrast) modulated an inhibitory conductance almost exclusively (Fig. 9). This response can be explained by the pathway: rod $\rightarrow$ rod bipolar $\rightarrow$ AII cell $\rightarrow$ ganglion cell. The other route $($ rod $\rightarrow$ 
cone $\rightarrow$ cone bipolar $\rightarrow$ ganglion cell) must be relatively inactive under this condition. Thus, rods drive the AII circuit at all light levels, but as light level decreases, the pathway for their drive switches between the cone bipolar circuit to the rod bipolar circuit (Xin and Bloomfield, 1999; Trexler et al., 2005; Pang et al., 2007).

\section{OFF bipolar input to the AII cell}

We have not considered here an additional synaptic pathway to the AII cell. OFF bipolar cells synapse onto AII cells, suggesting that OFF bipolar cells can excite the AII, in addition to receiving inhibition from the AII (Strettoi et al., 1992; Chun et al., 1993; Xin and Bloomfield, 1999). Under most conditions, the AII cell depolarizes at light onset, suggesting that $\mathrm{ON}$ bipolar excitation dominates the light response. However, under certain conditions, the AII shows an excitatory response at light offset (Xin and Bloomfield, 1999). How does this synapse fit into our model? Some feedforward inhibition onto the OFF ganglion cell (Fig. 6E) could possibly be explained by this synaptic pathway (cone $\rightarrow$ OFF cone bipolar $\rightarrow$ AII cell $\rightarrow$ OFF ganglion cell). However, at present, we cannot distinguish this from other types of amacrine cell that could play the same role (Kolb and Nelson, 1993).

\section{Impact of the disinhibition pathway for OFF ganglion cells in situ}

For OFF cells at the lowest contrast level tested (2.5\%), the negative conductance associated with disinhibition was approximately twice the magnitude of the positive conductance associated with excitation (Fig. 5). Here, we set $E_{\mathrm{Cl}}$ to be -67 $\mathrm{mV}$, but in situ we expect it to be more negative, approximately $-80 \mathrm{mV}$ (Murphy and Rieke, 2006); we expect $E_{\text {cation }}$ to be $\sim 0 \mathrm{mV}$. Furthermore, OFF ganglion cells rest between -60 and $-65 \mathrm{mV}$ (Zaghloul et al., 2003; Manookin and Demb, 2006). Thus, the driving force on excitation is three to four times larger than the driving force on inhibition. Taking into account the conductances and driving forces, disinhibition should generate approximately two-thirds of the inward current compared with excitation for threshold responses at $V_{\text {rest }}$ (Fig. 10). As the cell depolarizes from rest, the impact of disinhibition would increase. This analysis probably underestimates the complete drive from the AII circuit, which could also contribute by disinhibiting the OFF bipolar terminal to drive the excitatory conductance of the ganglion cell (Molnar and Werblin, 2007). Thus, under daylight conditions, the AII circuit contributes substantially to low-contrast responses through disinhibition of the OFF pathway.

\section{References}

Albrecht DG, Hamilton DB (1982) Striate cortex of monkey and cat: contrast response function. J Neurophysiol 48:217-237.

Amthor FR, Takahashi ES, Oyster CW (1989) Morphologies of rabbit retinal ganglion cells with complex receptive fields. J Comp Neurol 280:97-121.

Bloomfield SA, Dacheux RF (2001) Rod vision: pathways and processing in the mammalian retina. Prog Retin Eye Res 20:351-384.

Boos R, Schneider H, Wassle H (1993) Voltage- and transmitter-gated currents of all-amacrine cells in a slice preparation of the rat retina. J Neurosci 13:2874-2888.

Borg-Graham LJ (2001) The computation of directional selectivity in the retina occurs presynaptic to the ganglion cell. Nat Neurosci 4:176-183.

Brainard DH (1997) The psychophysics toolbox. Spat Vis 10:433-436.

Chen S, Diamond JS (2002) Synaptically released glutamate activates extra-

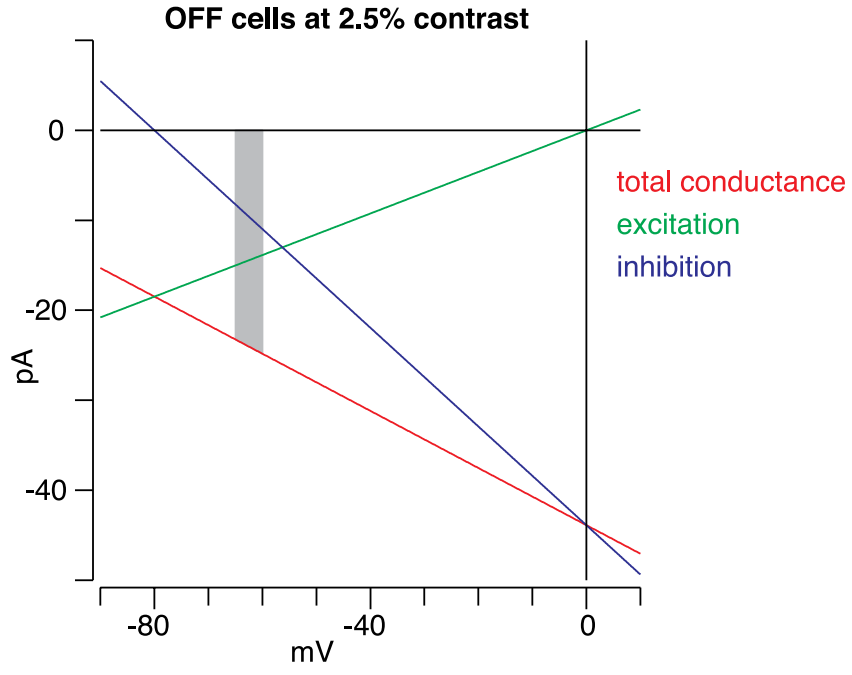

Figure 10. Disinhibition contributes substantially to low-contrast responses in OFF ganglion cells. Red line shows the total conductance measured from $380 \mathrm{FF}$ cells at the lowest contrast tested $(2.5 \%)$, which is near the threshold for responding. $E_{\mathrm{Cl}}$ was shifted to $-80 \mathrm{mV}$, the expected reversal potential for inhibition in situ (see Discussion). The underlying excitatory and inhibitory conductances are shown in green and blue, respectively. The expected resting potential for OFF cells in situ is between -60 and $-65 \mathrm{mV}$ (gray strip). Within this range, disinhibition provides approximately two-thirds the current as excitation.

synaptic NMDA receptors on cells in the ganglion cell layer of rat retina. J Neurosci 22:2165-2173.

Chun MH, Han SH, Chung JW, Wassle H (1993) Electron microscopic analysis of the rod pathway of the rat retina. J Comp Neurol 332:421-432.

Cohen E, Sterling P (1990) Convergence and divergence of cones onto bipolar cells in the central area of cat retina. Philos Trans R Soc Lond B Biol Sci 330:323-328.

Cohen ED (1998) Interactions of inhibition and excitation in the lightevoked currents of $\mathrm{X}$ type retinal ganglion cells. J Neurophysiol 80:2975-2990.

Cohen ED, Miller RF (1999) The network-selective actions of quinoxalines on the neurocircuitry operations of the rabbit retina. Brain Res 831:206-228.

Cohen ED, Zhou ZJ, Fain GL (1994) Ligand-gated currents of alpha and beta ganglion cells in the cat retinal slice. J Neurophysiol 72:1260-1269.

Dacey D, Packer OS, Diller L, Brainard D, Peterson B, Lee B (2000) Center surround receptive field structure of cone bipolar cells in primate retina. Vision Res 40:1801-1811.

Dacey DM (1999) Primate retina: cell types, circuits and color opponency. Prog Retin Eye Res 18:737-763.

Dacheux RF, Raviola E (1986) The rod pathway in the rabbit retina: a depolarizing bipolar and amacrine cell. J Neurosci 6:331-345.

Deans MR, Volgyi B, Goodenough DA, Bloomfield SA, Paul DL (2002) Connexin 36 is essential for transmission of rod-mediated visual signals in the mammalian retina. Neuron 36:703-712.

Demb JB, Haarsma L, Freed MA, Sterling P (1999) Functional circuitry of the retinal ganglion cell's nonlinear receptive field. J Neurosci 19:9756-9767.

Demb JB, Zaghloul K, Sterling P (2001a) Cellular basis for the response to second-order motion cues in $\mathrm{Y}$ retinal ganglion cells. Neuron 32:711-721.

Demb JB, Zaghloul K, Haarsma L, Sterling P (2001b) Bipolar cells contribute to nonlinear spatial summation in the brisk-transient $(\mathrm{Y})$ ganglion cell in mammalian retina. J Neurosci 21:7447-7454.

DeVries SH (2000) Bipolar cells use kainate and AMPA receptors to filter visual information into separate channels. Neuron 28:847-856.

DeVries SH, Baylor DA (1995) An alternative pathway for signal flow from rod photoreceptors to ganglion cells in mammalian retina. Proc Natl Acad Sci USA 92:10658-10662.

Diamond JS, Copenhagen DR (1993) The contribution of NMDA and non- 
NMDA receptors to the light-evoked input-output characteristics of retinal ganglion cells. Neuron 11:725-738.

Dumitrescu ON, Protti DA, Majumdar S, Zeilhofer HU, Wassle H (2006) Ionotropic glutamate receptors of amacrine cells of the mouse retina. Vis Neurosci 23:79-90.

Enroth-Cugell C, Robson JG (1966) The contrast sensitivity of retinal ganglion cells of the cat. J Physiol (Lond) 187:517-552.

Famiglietti Jr EV, Kolb H (1975) A bistratified amacrine cell and synaptic circuitry in the inner plexiform layer of the retina. Brain Res 84:293-300.

Feigenspan A, Teubner B, Willecke K, Weiler R (2001) Expression of neuronal connexin 36 in AII amacrine cells of the mammalian retina. J Neurosci 21:230-239.

Hack I, Peichl L, Brandstatter JH (1999) An alternative pathway for rod signals in the rodent retina: rod photoreceptors, cone bipolar cells, and the localization of glutamate receptors. Proc Natl Acad Sci USA 96:14130-14135.

Han Y, Massey SC (2005) Electrical synapses in retinal ON cone bipolar cells: subtype-specific expression of connexins. Proc Natl Acad Sci USA 102:13313-13318.

Hochstein S, Shapley RM (1976) Linear and nonlinear spatial subunits in Y cat retinal ganglion cells. J Physiol (Lond) 262:265-284.

Imai S, Suzuki T, Sato K, Tokimasa T (1999) Effects of quinine on three different types of potassium currents in bullfrog sympathetic neurons. Neurosci Lett 275:121-124.

Kalloniatis M, Sun D, Foster L, Haverkamp S, Wassle H (2004) Localization of NMDA receptor subunits and mapping NMDA drive within the mammalian retina. Vis Neurosci 21:587-597.

Kolb H (1979) The inner plexiform layer in the retina of the cat: electron microscopic observations. J Neurocytol 8:295-329.

Kolb H, Famiglietti EV (1974) Rod and cone pathways in the inner plexiform layer of cat retina. Science 186:47-49.

Kolb H, Nelson R (1993) OFF-alpha and OFF-beta ganglion cells in cat retina: II. Neural circuitry as revealed by electron microscopy of HRP stains. J Comp Neurol 329:85-110.

Lee EJ, Kim HJ, Kim IB, Park JH, Oh SJ, Rickman DW, Chun MH (2003a) Morphological analysis of disabled-1-immunoreactive amacrine cells in the guinea pig retina. J Comp Neurol 466:240-250.

Lee EJ, Han JW, Kim HJ, Kim IB, Lee MY, Oh SJ, Chung JW, Chun MH (2003b) The immunocytochemical localization of connexin 36 at rod and cone gap junctions in the guinea pig retina. Eur J Neurosci 18:2925-2934.

Li W, Keung JW, Massey SC (2004) Direct synaptic connections between rods and OFF cone bipolar cells in the rabbit retina. J Comp Neurol $474: 1-12$.

Lin B, Jakobs TC, Masland RH (2005) Different functional types of bipolar cells use different gap-junctional proteins. J Neurosci 25:6696-6701.

Manookin MB, Demb JB (2006) Presynaptic mechanism for slow contrast adaptation in mammalian retinal ganglion cells. Neuron 50:453-464.

Marc RE (1999a) Mapping glutamatergic drive in the vertebrate retina with a channel-permeant organic cation. J Comp Neurol 407:47-64.

Marc RE (1999b) Kainate activation of horizontal, bipolar, amacrine, and ganglion cells in the rabbit retina. J Comp Neurol 407:65-76.

Margolis DJ, Detwiler PB (2007) Different mechanisms generate maintained activity in ON and OFF retinal ganglion cells. J Neurosci 27:5994-6005.

Menger N, Pow DV, Wassle H (1998) Glycinergic amacrine cells of the rat retina. J Comp Neurol 401:34-46.

Mills SL, Massey SC (1995) Differential properties of two gap junctional pathways made by AII amacrine cells. Nature 377:734-737.

Mills SL, O’Brien JJ, Li W, O’Brien J, Massey SC (2001) Rod pathways in the mammalian retina use connexin 36. J Comp Neurol 436:336-350.

Molnar A, Werblin F (2007) Inhibitory feedback shapes bipolar cell responses in the rabbit retina. J Neurophysiol 98:3423-3435.

Muller F, Wassle H, Voigt T (1988) Pharmacological modulation of the rod pathway in the cat retina. J Neurophysiol 59:1657-1672.

Murphy GJ, Rieke F (2006) Network variability limits stimulus-evoked spike timing precision in retinal ganglion cells. Neuron 52:511-524.

Murphy GJ, Rieke F (2008) Signals and noise in an inhibitory interneuron diverge to control activity in nearby retinal ganglion cells. Nat Neurosci 11:318-326.

Nakajima Y, Iwakabe H, Akazawa C, Nawa H, Shigemoto R, Mizuno N, Nakanishi S (1993) Molecular characterization of a novel retinal metabotropic glutamate receptor mGluR6 with a high agonist selectivity for L-2-amino-4-phosphonobutyrate. J Biol Chem 268:11868-11873.

Nomura A, Shigemoto R, Nakamura Y, Okamoto N, Mizuno N, Nakanishi S (1994) Developmentally regulated postsynaptic localization of a metabotropic glutamate receptor in rat rod bipolar cells. Cell 77:361-369.

Pan F, Mills SL, Massey SC (2007) Screening of gap junction antagonists on dye coupling in the rabbit retina. Vis Neurosci 24:609-618.

Pang JJ, Gao F, Wu SM (2003) Light-evoked excitatory and inhibitory synaptic inputs to ON and OFF $\alpha$ ganglion cells in the mouse retina. J Neurosci 23:6063-6073.

Pang JJ, Abd-El-Barr MM, Gao F, Bramblett DE, Paul DL, Wu SM (2007) Relative contributions of rod and cone bipolar cell inputs to AII amacrine cell light responses in the mouse retina. J Physiol (Lond) 580:397-410.

Peichl L (1989) Alpha and delta ganglion cells in the rat retina. J Comp Neurol 286:120-139.

Pelli DG (1997) The VideoToolbox software for visual psychophysics: transforming numbers into movies. Spat Vis 10:437-442.

Rohlich P, van Veen T, Szel A (1994) Two different visual pigments in one retinal cone cell. Neuron 13:1159-1166.

Roska B, Molnar A, Werblin FS (2006) Parallel processing in retinal ganglion cells: how integration of space-time patterns of excitation and inhibition form the spiking output. J Neurophysiol 95:3810-3822.

Sagdullaev BT, McCall MA, Lukasiewicz PD (2006) Presynaptic inhibition modulates spillover, creating distinct dynamic response ranges of sensory output. Neuron 50:923-935.

Sassoe-Pognetto M, Wassle H, Grunert U (1994) Glycinergic synapses in the rod pathway of the rat retina: cone bipolar cells express the $\alpha 1$ subunit of the glycine receptor. J Neurosci 14:5131-5146.

Schiller PH (1992) The ON and OFF channels of the visual system. Trends Neurosci 15:86-92.

Schubert T, Degen J, Willecke K, Hormuzdi SG, Monyer H, Weiler R (2005) Connexin36 mediates gap junctional coupling of alpha-ganglion cells in mouse retina. J Comp Neurol 485:191-201.

Singer JH (2007) Multivesicular release and saturation of glutamatergic signalling at retinal ribbon synapses. J Physiol (Lond) 580:23-29.

Singer JH, Diamond JS (2003) Sustained $\mathrm{Ca}^{2+}$ entry elicits transient postsynaptic currents at a retinal ribbon synapse. J Neurosci 23:10923-10933.

Slaughter MM, Miller RF (1981) 2-amino-4-phosphonobutyric acid: a new pharmacological tool for retina research. Science 211:182-185.

Smith RG, Freed MA, Sterling P (1986) Microcircuitry of the dark-adapted cat retina: functional architecture of the rod-cone network. J Neurosci 6:3505-3517.

Soucy E, Wang Y, Nirenberg S, Nathans J, Meister M (1998) A novel signaling pathway from rod photoreceptors to ganglion cells in mammalian retina. Neuron 21:481-493.

Srinivas M, Hopperstad MG, Spray DC (2001) Quinine blocks specific gap junction channel subtypes. Proc Natl Acad Sci USA 98:10942-10947.

Sterling P (2004) How retinal circuits optimize the transfer of visual information. In: The visual neurosciences (Chalupa LM, Werner JS, eds), pp 234-259. Cambridge, MA: MIT.

Strettoi E, Raviola E, Dacheux RF (1992) Synaptic connections of the narrow-field, bistratified rod amacrine cell (AII) in the rabbit retina. J Comp Neurol 325:152-168.

Tagawa Y, Sawai H, Ueda Y, Tauchi M, Nakanishi S (1999) Immunohistological studies of metabotropic glutamate receptor subtype 6-deficient mice show no abnormality of retinal cell organization and ganglion cell maturation. J Neurosci 19:2568-2579.

Taylor WR, Vaney DI (2002) Diverse synaptic mechanisms generate direction selectivity in the rabbit retina. J Neurosci 22:7712-7720.

Trexler EB, Li W, Massey SC (2005) Simultaneous contribution of two rod pathways to AII amacrine and cone bipolar cell light responses. J Neurophysiol 93:1476-1485.

Tsukamoto Y, Morigiwa K, Ueda M, Sterling P (2001) Microcircuits for night vision in mouse retina. J Neurosci 21:8616-8623. 
Veruki ML, Hartveit E (2002) Electrical synapses mediate signal transmission in the rod pathway of the mammalian retina. J Neurosci 22:10558-10566.

Volgyi B, Abrams J, Paul DL, Bloomfield SA (2005) Morphology and tracer coupling pattern of alpha ganglion cells in the mouse retina. J Comp Neurol 492:66-77.

Wang P, Slaughter MM (2005) Effects of GABA receptor antagonists on retinal glycine receptors and on homomeric glycine receptor alpha subunits. J Neurophysiol 93:3120-3126.

Wassle H, Schafer-Trenkler I, Voigt T (1986) Analysis of a glycinergic inhibitory pathway in the cat retina. J Neurosci 6:594-604.

Werblin FS, Dowling JE (1969) Organization of the retina of the mudpuppy, Necturus maculosus. II. Intracellular recording. J Neurophysiol 32:339-355.

Xia Y, Nawy S (2003) The gap junction blockers carbenoxolone and 18beta- glycyrrhetinic acid antagonize cone-driven light responses in the mouse retina. Vis Neurosci 20:429-435.

Xin D, Bloomfield SA (1999) Comparison of the responses of AII amacrine cells in the dark- and light-adapted rabbit retina. Vis Neurosci 16:653-665.

Yamada ES, Bordt AS, Marshak DW (2005) Wide-field ganglion cells in macaque retinas. Vis Neurosci 22:383-393.

Yin L, Smith RG, Sterling P, Brainard DH (2006) Chromatic properties of horizontal and ganglion cell responses follow a dual gradient in cone opsin expression. J Neurosci 26:12351-12361.

Zaghloul KA, Boahen K, Demb JB (2003) Different circuits for ON and OFF retinal ganglion cells cause different contrast sensitivities. J Neurosci 23:2645-2654.

Zhang J, Li W, Hoshi H, Mills SL, Massey SC (2005) Stratification of alpha ganglion cells and ON/OFF directionally selective ganglion cells in the rabbit retina. Vis Neurosci 22:535-549. 